\title{
Assessing Public Support for Terrorism Over Time
}

Sandy Schumann*, University College London, Department of Security and Crime Science, s.schumann@ucl.ac.uk

Bettina Rottweiler, University College London, Department of Security and Crime Science, bettina.rottweiler.16@ucl.ac.uk

Paul Gill, University College London, Department of Security and Crime Science, pau.gill@ucl.ac.uk

*corresponding author

Acknowledgments of funding: This project has received funding from the European Research Council (ERC) under the European Union's Horizon 2020 research and innovation programme (grant agreement No 758834). 


\section{Assessing Public Support for Terrorism Over Time}

Public support for terrorism reflects people's sympathy for terrorist groups or tactics; it is influenced by and, in turn, shapes terrorists' campaigns as well as counter-terrorism measures. To date, longterm trends of public opinion about terrorism have been assessed in case studies and through descriptive statistics. Systematic analyses that specify whether and how public support for terrorism has changed over time are not available. We addressed this gap in the literature and conducted timeseries analyses of eight waves of data (2004-2011) from the Pew Global Attitudes Survey. Including responses from 15 Muslim-majority countries, $N=43255$, we showed that the percentage of people who believed that suicide terrorism was justified decreased between 2005 and 2007, after which support remained at a lower level (one structural breakpoint). Results also highlighted that depending on how public opinion was operationalised, the same data could inform an opposing narrative about support for terrorism. Notably, when analyses were replicated with a mean composite score of the answer options 'often', 'sometimes', and 'rarely justified', the percentage of people who thought that terrorism was 'ever justified' was reduced in 2005 before increasing again in 2008 (two structural breakpoints). Pre-registration of studies is therefore crucial to avoid selective analyses.

Key words: support for terrorism, public opinion, time-series analysis, open science 


\section{Assessing Public Support for Terrorism Over Time}

"The strongest weapon which the mujahedeen enjoy ... is popular support from the Muslim masses in Iraq, and the surrounding Muslim countries. So we must maintain this support as best we can, and we should strive to increase it ... In the absence of this popular support, the Islamic mujahed movement would be crushed in the shadows ... The mujahed movement must avoid any action that the masses do not understand or approve" (letter from Ayman al-Zawahiri to Abu Musab alZarqawi, who later led ISIS, released in October 2005; Global Security, 2020)

In the above quote from 2005, the current head of Al Qaeda, Ayman al-Zawahiri, outlines that the success of the group's plans, that is, defeating the U.S. Army in Iraq and establishing an Islamic Caliphate, depends on the extent to which the general population in Muslimmajority countries sympathises with and endorses Al Qaeda's actions. Public support for terrorists is an indicator of their perceived legitimacy (Kruglanski \& Fishman, 2006) and can enable terrorist actors to establish political power (Bueno de Mesquita, 2005). Public opinion in favour of terrorism further reflects the (scale of the) radical milieu (Malthaner \& Waldmann, 2014) and complicit surround (Richardson, 2006), which provides material resources, such as safe houses, money, or intelligence, to ensure the survival of a group or movement (Schmid, 2017).

Public support for terrorism is thought to fluctuate in response to the campaigns of terrorist actors, governments' counter-terrorism measures, as well as changing social and political conditions (Bloom, 2004; Bueno de Mesquita, 2005; Siqueira \& Sandler, 2007). To date, though, few empirical analyses have systematically assessed trends of public opinion about terrorism over time. Conclusions are largely based on country-specific case studies (e.g., Bloom, 2004; Bueno de Mesquita, 2005; Schuurman, 2013) and descriptive data (e.g., Pew Research, 2011; Wilke \& Samaranayake, 2006). The latter work, in particular, claims an overall reduction in public support for terrorism in Muslim-majority countries since the early 2000s. Given the methodological 
limitations of these analyses, it is, however, not possible to conclude if the observed (descriptive) patterns reflect statistically significant differences. Moreover, it can neither be specified how nor when opinions have changed; as a result, key events that facilitated a shift in support cannot be determined.

The present research aims to address these gaps in three important ways. Drawing on the Pew Global Attitudes Survey, and including data from 15 Muslim-majority countries, we apply time-series analyses to, firstly, investigate whether public support for suicide terrorism has changed between 2004 and 2011. Secondly, we assess if (potential) shifts in public opinion represent a linear trend or are defined by critical breakpoints, that is, a drastic increase or decrease in support at a specific time point (i.e., year). We further explore the extent to which developments of public support for suicide terrorism over time are replicated for different operationalisations of public opinion. We conduct separate analyses for key answer options in the Pew Global Attitudes Survey (e.g., suicide terrorism is 'sometimes', 'often', 'rarely', or 'never' justified) as well as for two types of composite scores that were used in previous research.

\section{Public Support for Terrorism}

Public support for terrorism can be distinguished into symbolic and material support (Paul, 2009; Schmid, 2013). This paper focuses on the former, that is, verbal expressions of sympathy with and justification of terrorism, terrorist groups or their tactics, often captured in public opinion polls and population surveys. The unanimous message from previous studies, notably those conducted in Muslim-majority countries, is that the majority of people do not justify terrorism and do not endorse groups like ISIS (e.g., Lipka, 2017; Pew Research, 2011; Poushter, 2015; Schmid, 2017; Tessler, Robbins, \& Jamal, 2016). In addition, concern about (Islamic) extremism is reported to be high (Poushter, 2015). Differences in the level of support are, however, observed when considering different terrorist actors and targets. For example, a poll conducted in 2014 showed that $34 \%, 31 \%$, and $29 \%$ of respondents in Kuwait, Saudi Arabia, and the United Arab Emirates respectively reported very positive or fairly positive views of the Muslim Brotherhood. Support for 
ISIS ranged in the same population between three and five percent (Pollock, 2014). Public support is also lower when questions emphasise that terrorist attacks target civilians but it is higher when a reference is made to US military targets (Medoff \& Ciolek, 2009; Shafiq \& Sinno, 2010). Attacks against outgroup members are considered more justified than those against ingroup members (Kaltenthaler, Miller, Ceccoli, \& Gelleny, 2010).

\section{Changes in Public Support for Terrorism Over Time}

Public support for terrorism, as all public opinion, is likely to change over time. Indeed, Siqueira and Sandler (2007) stated that "terrorists and the government face ... a competition over who will win over a base of potential supporters" (p. 879). Specifically, it has been argued that public support for terrorist groups may increase as governments spend on counter-terrorism measures instead of public goods, which should reduce the threshold for supporting terrorism (Siqueira \& Sandler, 2007). In turn, if the opportunity costs of shifting government resources to counter terrorism are low, for instance, because the population is well-off, the threshold for supporting terrorism should be enhanced, resulting in a more fragile terrorist support base (Siqueira \& Sandler, 2007).

Conversely, public support for terrorism can increase in response to campaigns and attacks of terrorist groups. Firstly, terrorist attacks may be used to elicit government responses that the public - in particular those who terrorists seek to act for or who are already inclined to support terrorism - perceive to be out of proportion (propaganda of the deed; Bueno de Mesquita \& Dickson, 2007). Terrorist attacks that are committed despite active security measures also highlight that the group is strong and committed, while exposing the vulnerability of the target, which may encourage support for terrorism (rather than state actors) (Sharvit et al., 2015). Notably, Bloom (2004) proposed that Palestinians' public support for suicide terrorism increased following a growing number of suicide attacks after the Oslo process had failed in 2000. Different factions, such as Hamas and Fatah, were thought to outbid each other with attacks to compete over public support; suicide attacks by specific factions thus should have increased the level of support for the 
respective group (Jaeger, Klor, Miaari, \& Paserman, 2010). Byrm and Araj (2008) failed to provide evidence for this hypothesis in a reanalysis of Bloom's (2004) data. Jaeger and colleagues (2010), however, showed that attacks committed by Hamas against Israeli targets predicted stronger public support for the group (see as well Sharvit and colleagues, 2015). Support for Hamas and Fatah did not change when other factions committed attacks (Jaeger et al., 2010).

An alternative explanation for the documented support for suicide terrorism in Palestine may be the persisting social and political conditions (see Siqueira \& Sandler, 2007). Paul (2009) proposed that the public expresses sympathy with terrorism as a result of ongoing experiences of humiliation, frustration, alienation and hatred, living under a repressive regime, and lacking opportunities for political expression and freedom (Paul, 2009). If the political opportunity structure in a country is restricted, if certain groups in society are continuously the victim of systemic discrimination and are alienated by governments, public support for terrorism can increase given that terrorist groups offer (or promise to offer) solutions to the social ills, providing, for instance, social services to deprived populations.

\section{Assessing Public Support for Terrorism with Public Opinion Surveys}

In addition to case studies (e.g., Schuurman, 2013) and theoretical modeling (Bueno de Mesquita \& Dickson, 2007; Siqueira \& Sandler, 2007), public opinion surveys provide the most detailed insights into changes of public support for terrorism over time. Notably, the Pew Global Attitudes Survey (PGAS) has tracked public endorsement of terrorist actors and suicide terrorism in numerous Muslim-majority countries between 2002 and 2014. Analyses of the survey data have, for instance, shown that views of Hezbollah became increasingly unfavourable in five countries in the Middle East between 2007 and 2014; views of Palestinians of Hamas became less favourable in the same period (Pew Research, 2014; see similar patterns when assessing support for Osama bin Laden between 2003 and 2011; Pew Research, 2011). Indeed, publications by the Pew Research Center concluded repeatedly that support for terrorism in Muslim-majority countries has decreased since the early 2000s (Lipka, 2017; Pew Research, 2011; Wilke \& Samaranayake, 2006). 
What is striking is that to date, and to our knowledge, no inferential statistical methods have been applied to examine whether the differences in public opinion that were observed in the PGAS data were indeed statistically significant. Conclusions were instead purely based on annual descriptive statistics. Using a hypothetical example, if $42 \%$ of people had reported that suicide terrorism was 'often justified' in one year and 35\% endorsed the same answer in the following year, this would be considered as decreased support. Of course, without inferential tests, it is not possible to judge if a 7\% reduction is indeed different from zero and not a random sampling fluctuation, due to chance alone.

Moreover, the pattern of change - if any change in public support for terrorism did in fact occur - has not been specified systematically, which makes it difficult to propose reasons that may explain a particular trend. Taylor (1980) proposed that public opinion can be described, on one hand, by linear developments (i.e., transitive gerund theory), that is, an ongoing and persistent increase or decrease in public support for terrorism. Alternatively, one or more structural breakpoints may be determined at which opinions change drastically - "public opinion measures

show a great deal of statistically significant 'bounce"” (i.e., social catastrophe; Taylor, 1980, p. 87); after the breakpoint, opinions can remain stable or grow/weaken in a linear fashion. The latter pattern would highlight key events, rather than ongoing conditions, that have caused opinions to shift.

\section{Operationalising Public Support for Terrorism}

Reporting levels and trends of public support for terrorism is undoubtedly a sensitive and politically contentious matter. Showing, for instance, that the majority of residents in Muslimmajority countries consider terrorism to be 'never justified' can serve to rebut stereotypes and reduce prejudice towards Muslims. Likewise, indicating that public support for terrorism has decreased over time may document that terrorist actors are not gaining ground and that efforts to counter violent extremism are fruitful. 
Researcher's degrees of freedom (Simmons, Nelson, \& Simonsohn, 2011) mean that when conducting a study, one has several options how to code variables, operationalise concepts, or transform measures. The respective choices can affect the results and, consequently, the conclusion that is drawn from the data. A specific concern when studying public support of terrorism is the variation in approaches to operationalise public opinion. In the PGAS, for example, respondents indicate the extent to which suicide terrorism is 'often', 'sometimes', 'rarely', or 'never justified'. The answer options are assigned values ranging from one to four. In many analyses, only results of some of these four answer options are presented (Pew Research, 2011; 2014). Pew Research also frequently combines the answer options that terrorism is 'often' and 'sometimes justified' as well as 'rarely' and 'never justified' into two data points respectively. This data transformation, however, is not applied consistently (Wilke \& Samaranayake, 2006): Comparing support for suicide terrorism as assessed in 2002 and 2005, the percentage of respondents who indicated 'often' and 'sometimes justified' were combined to one score while the answers 'rarely' and 'never justified' were presented separately.

Data from the PGAS has further been recoded into a dichotomous variable where the answer options 'often', 'sometimes', and 'rarely justified' indicate that terrorism is 'ever justified', which is then contrasted against terrorism being 'never justified' (Cherney \& Povey, 2013; Fair \& Shepherd, 2006; Tessler \& Robbins, 2007). Finally, variation can also be observed with regards to whether the key metric of analysis is the percentage of respondents who endorsed a certain answer (used by all of Pew's own reports) or the numeric values of the answer options (i.e., one to four). Applying the latter rationale, Fair and Shepherd (2006) created mean scores, thus treating the measure as at least interval-scaled, while Cherney and Povey (2013), for instance, recoded values of answer options into a dichotomous variable. The rationale behind the various data transformations has not been explicitly explained by any of the authors. In addition, result patterns were not replicated while using alternative operationalisations, which could serve as a robustness check to highlight that certain findings are not only observed when particular variables are chosen. 


\section{The Present Research}

We aim to address the aforementioned challenges of previous research and advance the literature in three important ways. Firstly, we apply time-series analyses to data from the PGAS to test whether public support for suicide terrorism has changed between 2004 and 2011 in Muslimmajority countries (Research Question 1). Doing so, we assess the (potential) pattern of change; we explore if linear trends or such defined by opinion breakpoints best characterise the development (Research Question 2). Should the latter be suitable to describe public opinion trends, we specify in which year public support for suicide terrorism has changed drastically. We further investigate whether the developments in public support for terrorism over time differ depending on how public opinion is operationalised (Research Question 3). We introduce two sets of operationalisations: a) tracking four distinct answer options separately and interpreting changes holistically as well as b) creating composite scores of answer options as done in previous studies.

\section{Method}

Data and Sample. Analyses were based on data from the Pew Global Attitudes Survey, a multi-country multi-wave public opinion survey. Table 1 includes information about the 15 countries that were selected for the analyses. We only drew on responses from countries where a) data on public support for terrorism was collected and b) data from representative adult population samples was available. Samples were described as nationally representative if $80 \%$ of the adult population in a country were reflected. We further only analysed data from eight of the 11 waves of the PGAS such that a time-series with fixed yearly intervals and no gaps could be specified. The Pew Research Center collected data yearly from 2004 to 2011. No data was collected in 2003 and 2012. The available data from 2002, 2013 and 2014 therefore had to be excluded from the present research.

As the Pew Global Attitudes Survey is not a panel study, new samples were drawn at each wave. In total, $N=43255$ respondents are included in our analysis (Table 1). All samples assessed in the present research are probability samples. The sampling error as well as response rates per 
country/wave are also documented in Table 1. All participants were 18 years or older. We did not select responses based on religion such that respondents who do and who do not self-identify as Muslims are included in the analysis. Table 1 provides information about the sample sizes per country/wave as well as geographic information as reported by Pew Research.

\section{Table 1 here}

Data Collection Procedure. Data for the PGAS was collected by professional (market) research companies in each of the countries. For the data used in this analysis, all data collection involved face-to-face interviews. Field work periods were largely synchronised but varied somewhat between countries (Table 1). More information about the data collection procedure and survey methodology is available online. ${ }^{1}$

Measure. The PGAS examines public support for terrorism with the following item: "Some people think that suicide bombing and other forms of violence against civilian targets are justified in order to defend Islam from its enemies. Other people believe that, no matter what the reason, this kind of violence is never justified. Do you personally feel that this kind of violence is often justified to defend Islam, sometimes justified, rarely justified, or never justified?” Respondents could also indicate that they preferred not to answer the question. The four answer options of interest are 'often', 'sometimes', 'rarely', and 'never justified'.

Data Transformation. We transformed answers to the aforementioned question to reflect different operationalisations of public support for terrorism. First, we calculated for each country in each wave the percentage of the overall sample that had endorsed each of the four answer options 'often', 'sometimes', 'rarely', and 'never justified'. Second, a mean score of the percentage of people who reported (in a particular country/wave) that terrorism is 'often' or 'sometimes justified' was created (i.e., operationalisation 'often/sometimes' (mean)). This procedure was then repeated by additionally including the answer option 'rarely justified'; this operationalisation of public

\footnotetext{
${ }^{1}$ https://www.pewresearch.org/methods/international-survey-research/
} 
opinion represents the perspective that terrorism is 'ever justified' (mean). Thirdly, the operationalisations 'often/sometimes justified' and 'ever justified' were created by adding up percentage points (rather than creating a mean) - 'often/sometimes justified' (sum) and 'ever justified' (sum).

To define the time-series data for analysis, an average score across all countries that were sampled in a particular wave was calculated for all operationalisations of public support for terrorism respectively (Table 2). By relying on these scores across countries, we could include data from countries in which surveys were only conducted in some of the eight waves.

Table 2 here

\section{Results}

The code to reproduce the analyses is available online (see Appendix for review). Raw data for all countries/waves is presented in the Supplementary Material (Note 1, Table S1-S8). All analyses were conducted with $R$ 3.2.6. We did not weight the raw data. As the full samples was included in all analyses, the error attributable to sampling and other random effects (Table 1) is with $95 \%$ confidence plus or minus the margin of error.

Analytical approach. In order to assess the research questions, we conducted time-series analyses (TSA). A time-series is a collection of data points that are/were collected in regular, fixed intervals and are documented in a natural temporal ordering (Montgomery, Jennings, \& Kulahci, 2008). An example of a time-series is a record of public opinion about terrorism that is captured yearly, for several years. TSA makes it possible to identify the structure that underlies such longitudinal data in order to investigate whether and how public support for terrorism has changed during a specific period. In the present study, we consider three alternative data structures and determine which one offers the best fit (or smallest discrepancy) from the observed survey data (see Kleinberg, van der Vegt, \& Gill, 2020). 
First, the Augmented Dickey-Fuller (ADF) test was conducted for each outcome measure (i.e., each operationalisation of public opinion) to examine whether the respective time-series was stationary. A stationary time-series does not imply that there was no change in public opinion. It rather suggests that the properties that generate the structure of the time-series remain stable over time such that the distribution of the data does not change when time passes. In a next step, we then fitted an intercept-only model, a linear temporal trend model, and a structural breakpoint model for each outcome measure.

The intercept-only model assumes that public support for terrorism did not change during the study period, such that the regression coefficient in the model is zero. The linear trend model stipulates a strictly linear temporal progression with a stable non-zero regression coefficient. The structural breakpoint model proposes $n$ structural breaks at which the non-zero regression coefficient changes significantly. The number and position of the breakpoints in the time-series is not pre-determined. To extract this latter information, Bayesian Information Criterion (BIC) plots were examined and the breakpoint model (as well as the other two models) was plotted to the observed data (Zeileis, Kleiber, Krämer, \& Hornik, 2003). All three models are non-nested. They were therefore compared using the Akaike's Information Criterion AIC (Akaike, 1974), Bayesian Information Criterion, as well as the mean absolute error (MAE), and the root mean squared error (RMSE). Better model fit, that is, less discrepancy from the observed data, was indicated by lower AIC, BIC, MAE, and RMSE values.

Time Series Analysis. Table 3 highlights the findings of the TSAs for all eight operationalisations of public opinion.

\section{Table 3 here}

Terrorism is Often Justified. The ADF test indicated that the time-series is stationary, Dickey-Fuller statistic $=-17.08, p=.010$. The breakpoint model fitted the data best (Table 3). The MAE of 2.21 suggests that the average discrepancy between the observed data and values predicted 
by the breakpoint model is $2.21 \%$. The BIC plot demonstrated one structural breakpoint. Plotting the intercept-only, linear and breakpoint models against the observed data revealed that the structural break occurred in 2005 (Figure 1). The percentage of people who reported that suicide terrorism was 'often justified' dropped at that point from $13.9 \%$ to 5\% (Table 2).

Figure 1 here

Terrorism is Sometimes Justified. The ADF test pointed out that the time-series is not stationary, Dickey-Fuller statistic $=.23, p=.990$. As for the previous analysis, the breakpoint model with one structural break fitted the data best (Table 3; Figure 2). Here, however, the breakpoint occurred in 2006 when the percentage of people who expressed the opinion that suicide terrorism was 'sometimes justified' dropped from $20.8 \%$ to $15.1 \%$ (Table 2).

\section{Figure 2 here}

Terrorism is Rarely Justified. The ADF test indicated that the time-series is stationary, Dickey-Fuller statistic $=-8.82, p=.010$. The breakpoint model with one break and the linear model fitted the data similarly well (Table 3). Plotting the models to the observed data, it is evident that the structural break occurred in 2007 (Figure 3). At this point, the percentage of people who stated that suicide terrorism is 'rarely justified' increased from $14.8 \%$ to $20.1 \%$ (Table 2).

Figure 3 here

Terrorism is Never Justified. The ADF test highlighted that the time-series is not stationary, Dickey-Fuller statistic $=-1.49, p=.767$. The AIC and BIC are lowest for the breakpoint model with one break (Table 3). The breakpoint occurred in 2005 (Figure 4). The percentage of people who believed that suicide terrorism is 'never justified' increased at that point from $44.1 \%$ to $49.6 \%$ (Table 2). 
Terrorism is Often/Sometimes Justified (mean). The ADF test also documented that the time-series is not stationary, Dickey-Fuller statistic $=-2.01, p=.569$. The breakpoint model with one break at 2005 fitted the data best (Table 3; Figure 5). In 2005, the percentage of people who expressed that suicide terrorism is 'often' or 'sometimes justified' decreased from $15.7 \%$ to $12.9 \%$ (Table 2).

\section{Figure 5 here}

Terrorism is Often/Sometimes Justified (sum). The ADF test indicated that the time-series is not stationary, Dickey-Fuller statistic $=-1.95, p=.590$. The breakpoint model with one break at 2005 fitted the data best (Table 3; Figure 6). The overall (sum) percentage of people who expressed that suicide terrorism is 'often' or 'sometimes justified' changed in that year from $31.3 \%$ to $25.8 \%$ (Table 2).

\section{Figure 6 here}

Terrorism is Ever Justified (mean). The ADF test showed that the time-series is not stationary, Dickey-Fuller statistic $=-1.18, p=.883$. A breakpoint model with two structural breaks fitted the data best (Table 3; Figure 7). The breaks occurred in 2005 and 2008. In 2005, the percentage of people who thought that suicide terrorism was 'ever justified' decreased from $17.1 \%$ to $15 \%$; in 2008 the percentage of people who held that opinion increased from $14.8 \%$ to $15.8 \%$ (Table 2).

\section{Figure 7 here}

Terrorism is Ever Justified (sum). The ADF test showed that the time-series is not stationary, Dickey-Fuller statistic $=-1.99, p=.580$. Contrary to the results that were achieved when creating a mean score, a breakpoint model with one structural break fitted the data best (Table 3; Figure 8). In line with the patterns identified in the majority of analyses, the break occurred in 2005 
when the overall (sum) percentage of people who thought that suicide terrorism was 'ever justified' decreased from $49.7 \%$ to $42.9 \%$ (Table 2).

\section{Figure 8 here}

\section{Discussion}

We reported analyses of data from the Pew Global Attitudes that examined whether and how public support for terrorism has changed between 2004 and 2011. Results showed that, in line with previous observations of descriptive data, public support for terrorism has decreased between 2004 and 2011 in Muslim-majority countries. Specifically, between 2005 and 2007, the percentage of respondents who believed that suicide terrorism was 'often' and 'sometimes justified' was reduced while the percentage of those who thought that suicide terrorism was 'rarely' and 'never justified' increased. Findings, however, also highlighted that the operationalisation of public opinion can affect what kind of trends are identified. Although breakpoint model provided overall the best fit, depending on what answer option was analysed, the years in which breaks occurred differed. Further, applying a commonly used dichotomisation of answer options, which distinguishes whether terrorism is 'ever' or 'never justified', we replicated the aforementioned drop in support in 2005 but documented also an increase of support for terrorism in 2008. Below we discuss these finding and elaborate on the study's limitations as well as suggestions for future research.

\section{Public Support for Terrorism Decreased}

Previous reports by the Pew Research Center emphasised that support for suicide terrorism had decreased in Muslim-majority countries since the early 2000s (Lipka, 2017; Pew Research, 2011; 2014; Wilke \& Samaranayake, 2006). Our analysis further specifies this conclusion and highlights that the shift in public opinion occurred between 2005 and 2007 after which support remained low. Assessing events or development that may have triggered the change in public opinion, we must examine incidents that affected residents in all Muslim-majority countries. 
Specifically, it is also worth considering the effects of people's experiences with suicide terrorism in their own country. People who have experienced suicide terrorism in their proximity and are aware of the potential victimisation of their ingroup - not just that of outgroups - could be expected to express less support for terrorism (Kaltenthaler et al., 2010). Between 2004 and 2008 terrorist attacks almost quadrupled around the world - the steepest increase during the study period (Global Terrorism Database, 2020). Taking into account only the countries included in our analysis, 133 suicide attacks had occurred between 2000 and 2005 compared with 35 between 2006 and 2011 (Supplementary Material, Note 2, Table S9). ${ }^{2}$

Anecdotal evidence also lends some evidence to confirm the speculation that experiencing terrorist attacks in one's proximity changes public support. After the US-led invasion of Iraq in 2003, an insurgency erupted. From 2003 to 2006, Sunnis and, later on, Shias extensively used suicide-bombing in order to force the coalition forces out of the country (Hafez, 2006). While the insurgency had initially relatively high levels of public support, this was reduced once the attacks became deadlier and more frequent (Ciolek, Ozdemir, \& Sullins, 2006; Hafez, 2006). In Bangladesh, 44\% of people reported in the PGAS from 2002 that suicide bombings were 'often/sometimes justified'. At that time, one suicide bombing had occurred in Bangladesh. Over the course of ten days in late 2005, Jamatul Mujahedin launched three suicide bombings against political targets killing 17 and injuring over 150. Bangladeshi citizens engaged in a one-day strike expressing their abhorrence to the suicide bombings. Bangladesh's leading Muslim cleric, Maolana Obaidul Haq, called for further protests against the bombings and encouraged sermons across the country to denounce suicide bombings. PGAS data from Bangladesh in 2007 showed that levels of support for suicide terrorism were reduced to $20 \%$. Equally, in Indonesia, the 2002 PGAS recorded that $26 \%$ considered suicide terrorism as 'often/sometimes justified'. Before the 2005 PGAS poll was undertaken, Indonesia experienced three mass casualty suicide bombings: the Bali bombing on

\footnotetext{
2 The difference, however, was largely driven by Israel where 94 attacks were recorded in 20002005 and nine attacks in 2006-2011. Unfortunately, PGAS data for Israel is only available for 2009 and 2011.
} 
a nightclub in October 2002, a bombing of a hotel in Jakarta in August 2003, and the attack on the Australian embassy in September 2004. Support for suicide bombings fell to $15 \%$ in 2005 . In October 2005, a second bombing in Bali killed 20 and injured over 100. After this bombing, support fell further to $10 \%$ in the 2006 PGAS poll.

Having discussed how terrorist attacks could have shaped public opinion, it is equally relevant to explore the possibility of reverse-causality, that is, the implications of the documented drop in public support for terrorist activities (see Bueno de Mesquita \& Dickson, 2007). Notably, Schuurman (2013) highlighted that if citizens' endorsement of terrorism increases, governments will find it harder to legitimise or implement counter-terrorism measures. In turn, if terrorists' tactics and methods are deemed as illegitimate or out of proportion, government's may use this opportunity to strengthen their resolve and pursue terrorists. Moreover, Sharvit and colleagues (2015) showed that higher public support for violence in Palestine predicted a larger number of future attacks on Israel. It may thus be speculated that the aforementioned reduction of suicide attacks from 2005 was the result of lower public support for terrorism in Muslim-majority countries. Strictly causal conclusions, of course, cannot be drawn. It is also noteworthy that while public support may be viewed as a regulator of the frequency and intensity of terror attacks, that role is reduced if external parties sponsor terrorist groups (Siqueira \& Sandler, 2007).

\section{Result Patterns Vary for Different Operationalisations of Public Opinion}

Although breakpoint models with one structural break provided the best fit for most operationalisations of public opinion, our results showed two types of variations in result patterns. Firstly, considering trends of different answer options separately, it is evident that break points were identified in different years, between 2005 and 2007. The extreme points of answer options - 'often' and 'never justified' - showed changes in 2005, while the less decisive answers 'sometimes' and 'rarely justified' changed in 2006 and 2007 respectively. Second, when combining the answer options 'often', 'sometimes', and 'rarely justified' as a mean score two opinion breaks, with an increased of support in 2008, were documented. 
Both discrepancies have unique implications for the conclusions that can be drawn from the results, especially if one was to consider a scenario where a researcher would only use one specific operationalisation and not, like here, a broad range of options that can be evaluated in its entirety. On one hand, those who want to identify specific events that have lead to a change in opinion will arrive at different suggestions if models point to different years at which breakpoints occurred. Consequentially, proposed counter-terrorism measures vary and their potential impact on future opinions is likely rendered less meaningful. On the other hand, dramatically different narratives about the public support for terrorism in Muslim-majority countries can be derived; they either suggest that a) support for suicide terrorism declined in 2005 and stayed low or that b) support for terrorism decreased for a few years only to increase again in 2008. Those who aim to portrait a specific - negative or positive - image of Muslims, can analyse the data in a selective manner to arrive at their intended conclusions.

In order to avoid such selective analysis and reporting, it is therefore crucial that analysis plans for studies are specified and documented before researchers know the data or the results. This process is called pre-registration and has become increasingly common across different disciplines (Nosek, Ebersole, DeHaven, \& Mellor, 2018). Authors publicly record central study design and analyses decisions, such as intended sample size, measures, data transformations as well as preferred statistical analyses, before data is collected or - at least - before it is analysed. Although this procedure appears at first especially suitable for primary data and deductive, quantitative methods, it is also applied to secondary data (Van den Akker et al., 2019) and explorative qualitative studies (Haven \& Van Grootel, 2019; Author, 2019). Many practical resources for how to complete pre-registrations are available through the Center for Open Science (2020).

\section{Limitations}

The aforementioned conclusions and recommendations must be considered in light of the following limitations. Firstly, the analysis only draws on data from residents in Muslim-majority countries, which is where the question examining support for suicide terrorism was asked in the 
PGAS. A similar approach has been taken by the ABC/BBC/ARD Iraq survey (BBC, 2008) and

The World Values Survey (1996-1997). Opinions of Muslims living in the West have been recorded less frequently (see Pew Global Attitudes Survey 2006 and 2007; Victoroff, Adelman, \& Matthews, 2012). Consequently, the present analysis can be generalised neither to Muslims nor non-Muslims in non-Muslim majority countries. We therefore encourage researchers to assess public opinion on terrorism in the broader, Western and non-Muslim, population. Doing so, will also shift the biased perceptions that if only Muslims are asked about terrorism, it must be only them who support it. In addition, due to not weighing the raw data to adjust for the probability of being included in the study or the sample design, we must acknowledge that the samples may not fully represent the population from which they were drawn.

Moreover, it is worth mentioning that the measure examining public support for terrorism may be conceptualised as verbal support for terrorism but does not allow conclusions about any active support that respondents may be willing to provide to terrorist actors (Schmid, 2017). As such, one should be cautious to interpret the findings as an indicator of the size of the radical milieu in the respective countries and certainly not draw conclusions about the degree of radicalisation. To approximate the latter, dedicated questions regarding respondents' willingness to use violence to attain political, religious, or social justice goals must be included in public opinion polls. For ethical and legal reasons this is, understandably, not feasible in all countries.

Finally, it must be noted that analyses were based on mean scores of public opinion that were calculated across several countries. It is a valid criticism that the included countries differ to some extent in terms of their experience with terrorism as well as overall political, social, economic conditions. Therefore, the observed trends may have been heavily affected by changes in only a few countries. Likewise, trends identified across all countries do not apply exactly to each individual country. Supplementary analyses (see Supplementary Material, Note 3) for Jordan and Turkey, for which data on all waves was available, highlight as well the overall trend of falling support, but deviations in result patterns occur. Lastly, it is important to keep in mind that the changes in public 
support for terrorism that were documented in the present research should not serve as a basis for forecasting how opinions will develop after the study period. Further analytical steps to advance the time-series analysis would have to be applied to achieve this.

\section{Conclusion}

Despite these limitations, we believe that the paper makes an important contribution to the literature, both in the fields of terrorism studies and public opinion research. We documented that across 15 Muslim-majority countries average support for terrorism fell between 2005 and 2007 and has remained low for the following five years. It is our hope that highlighting such insights might help dispel persisting negative stereotypes about Muslims. In addition, we showed that researchers' decisions on how to operationalise public opinion can have an effect on the kinds of opinion trends that are identified and, more importantly, the conclusions that are drawn. Fortunately, open science practices can help address the concerns that arise from such selective data analysis. 


\section{References}

Akaike, H. (1974). A new look at the statistical model identification. IEEE transactions on automatic control, 19(6), 716-723. DOI: 10.1109/TAC.1974.1100705

BBC (2008). Results of BBC/ABC News/NHK/ARD opinion poll conducted in Iraq. Available at: http://www.bbc.co.uk/pressoffice/pressreleases/stories/2008/03_march/17/iraq.shtml

Bloom, M. M. (2004). Palestinian suicide bombing: Public support, market share, and outbidding. Political Science Quarterly, 119(1), 61-88. DOI: 10.2307/20202305

Bueno de Mesquita, E. B. (2005). The quality of terror. American journal of political science, 49(3), 515-530. DOI: 10.1111/j.1540-5907.2005.00139.x

Bueno de Mesquita, E., \& Dickson, E. S. (2007). The propaganda of the deed: Terrorism, counterterrorism, and mobilization. American Journal of Political Science, 51(2), 364-381. DOI: $10.1111 / \mathrm{j} .1540-5907.2007 .00256 . x$

Brym, R. J., \& Araj, B. (2008). Palestinian suicide bombing revisited: A critique of the outbidding thesis. Political Science Quarterly, 123(3), 485-500. DOI:

Center for Open Science (2020). Pre-registration. Available at: https://www.cos.io/our-services/prereg

Ciolek M., Ozdemir, D., \& Sullins, B. (2006). What the Iraqi Public Wants. Available at: http://worldpublicopinion.net/wp-content/uploads/2017/08/Iraq_Jan06_rpt.pdf

Cherney, A., \& Povey, J. (2013). Exploring support for terrorism among muslims. Perspectives on terrorism, 7(3), 5-16. Available at: https://www.jstor.org/stable/26296936

Fair, C. C., \& Shepherd, B. (2006). Who supports terrorism? Evidence from fourteen Muslim countries. Coastal Management, 29(1), 51-74. DOI: 10.1080/10576100500351318

Global Security (2020). Zawahiri Zargawi Letter. Available at: https://www.globalsecurity.org/security/library/report/2005/zawahiri-zarqawiletter 9jul2005.htm

Global Terrorism Database (2020). Global Terrorism Database. Available at: 
https://www.start.umd.edu/gtd/

Hafez, M. M. (2006). Suicide terrorism in Iraq: A preliminary assessment of the quantitative data and documentary evidence. Studies in Conflict \& Terrorism, 29(6), 591-619. DOI: $10.1080 / 10576100600790878$

Haven, T., \& Van Grootel, D. L. (2019). Preregistering qualitative research. Accountability in Research, 26(3), 229-244. DOI: 10.1080/08989621.2019.1580147

Jaeger, D. A., Klor, E. F., Miaari, S. H., \& Paserman, M. D. (2010). Can militants use violence to win public support? Evidence from the second intifada (No. w16475). National Bureau of Economic Research. Available at: https://www.nber.org/papers/w16475

Kaltenthaler, K., Miller, W. J., Ceccoli, S., \& Gelleny, R. (2010). The sources of Pakistani attitudes toward religiously motivated terrorism. Studies in Conflict \& Terrorism, 33(9), 815-835. $10.1080 / 1057610 X .2010 .501424$

Kleinberg, B., van der Vegt, I., \& Gill, P. (2020). The temporal evolution of a far-right forum. Journal of Computational Social Science, 1-23. DOI: 10.1007/s42001-020-00064-x

Kruglanski, A. W., \& Fishman, S. (2006). The psychology of terrorism:“Syndrome” versus "tool” perspectives. Terrorism and Political Violence, 18(2), 193-215. DOI:

$10.1080 / 09546550600570119$

Lipka, M. (2017). Muslims and Islam: Key findings in the U.S. and around the world. Available at: https://www.pewresearch.org/fact-tank/2017/08/09/muslims-and-islam-key-findings-in-theu-s-and-around-the-world/

Malthaner, S., \& Waldmann, P. (2014). The radical milieu: Conceptualizing the supportive social environment of terrorist groups. Studies in Conflict \& Terrorism, 37(12), 979-998. DOI: $10.1080 / 1057610 X .2014 .962441$

Medoff, A. \& Ciolek, M. (2009). Public Opinion in the Islamic World on Terrorism, al Qaeda, and US Policies. University of Maryland. 
Montgomery, D. C., Jennings, C. L., \& Kulahci, M. (2008). Introduction to Time Series Analysis and Forecasting. New Jersey, USA: John \& Wiley \& Sons.

Nosek, B. A., Ebersole, C. R., DeHaven, A. C., \& Mellor, D. T. (2018). The preregistration revolution. Proceedings of the National Academy of Sciences, 115(11), 2600-2606. DOI: 10.1073/pnas.1708274114

Paul, C. (2009). How Do Terrorists Generate and Maintain Support?. In: Social Science for Counterterrorism: Putting the Pieces Together, Paul K. Davis and Kim Gragin (Eds.) pp. 113-150. Santa Monica, USA: RAND Cooperation.

Pew Research (2011). Muslim Americans: No Signs of Growth in Alienation or Support for Extremism. Available at: https://www.people-press.org/2011/08/30/muslim-americans-nosigns-of-growth-in-alienation-or-support-for-extremism/

Pew Research (2014) . Concerns about Islamic Extremism on the Rise in Middle East. Available at: https://www.pewresearch.org/global/2014/07/01/concerns-about-islamic-extremism-on-therise-in-middle-east/

Pollock, D. (2014). New Poll Shows Majority of Saudis, Kuwaitis, Emiratis Reject ISIS, Back Two State Solution with Israel. The Washington Institute for Near East Policy.

Poushter, J. (2015). In Nations with Significant Muslim Populations, much Disdain for ISIS. Pew Research.

Richardson, L. (2006) What Terrorists Want: Understanding the Enemy, Containing the Threat. New York: Random House.

Schmid, A. (2017). Public opinion survey. Data to measure sympathy and support for Islamist terrorism. The Hague, The Netherlands: International Centre for Counter-Terrorism.

Schuurman, B. (2013). Defeated by popular demand: Public support and counterterrorism in three western democracies, 1963-1998. Studies in Conflict \& Terrorism, 36(2), 152-175. DOI: 10.1080/1057610X.2013.747072

Shafiq, M., \& Sinno, A. H. (2010). Education, income, and support for suicide bombings: Evidence 
Running head: Public Support for Terrorism Over Time

from six Muslim countries. Journal of Conflict Resolution, 54(1), 146-178. DOI:

$10.1177 / 0022002709351411$

Sharvit, K., Kruglanski, A. W., Wang, M., Sheveland, A., Ganor, B., \& Azani, E. (2015).

Palestinian public opinion and terrorism: A two-way street?. Journal of Policing, Intelligence and Counter Terrorism, 10(2), 71-87. DOI: 10.1080/18335330.2015.1090526

Simmons, J. P., Nelson, L. D., \& Simonsohn, U. (2011). False-positive psychology: Undisclosed flexibility in data collection and analysis allows presenting anything as significant. Psychological Science, 22(11), 1359-1366. DOI: 10.1177/0956797611417632

Siqueira, K., \& Sandler, T. (2007). Terrorist backlash, terrorism mitigation, and policy delegation. Journal of Public Economics, 91(9), 1800-1815. DOI: 10.1016/j.jpubeco.2007.02.005

Taylor, D. G. (1980). Procedures for evaluating trends in public opinion. Public Opinion Quarterly, 44(1), 86-100. DOI: $10.1086 / 268568$

Tessler, M., \& Robbins, M. D. (2007). What leads some ordinary Arab men and women to approve of terrorist acts against the United States?. Journal of Conflict Resolution, 51(2), 305-328. DOI: $10.1177 / 0022002706298135$

Tessler, M., Robbins, M., \& Jamal, A. (2016). What do ordinary citizens in the Arab world really think about the Islamic State?" washingtonpost. com.

Van den Akker, O., Weston, S.J., Campbell, L., Chopik, W.J., Damian, R.I., Davis-Kean, P., Hall, A., Kosie, J., Kruse, E., Olsen, J. and Ritchie, S.J. (2019). Preregistration of secondary data analysis: A template and tutorial. Available at:

https://www.researchgate.net/profile/Jerome_Olsen/publication/337407273_Preregistration of secondary data analysis A template and tutorial/links/5ddbe18ea6fdccdb446408f9/Pr eregistration-of-secondary-data-analysis-A-template-and-tutorial.pdf

Victoroff, J., Adelman, J. R., \& Matthews, M. (2012). Psychological factors associated with support for suicide bombing in the Muslim diaspora. Political Psychology, 33(6), 791-809. DOI: 10.1111/j.1467-9221.2012.00913.x 
Wilke, R. \& Samaranayake, N. (2006). Where Terrorism Finds Support in the Muslim World. Pew Research.

The World Values Survey (2020). The World Values Survey. Available at: http://www.worldvaluessurvey.org/wvs.jsp

Zeileis, A., Kleiber, C., Krämer, W., \& Hornik, K. (2003). Testing and dating of structural changes in practice. Computational Statistics \& Data Analysis, 44(1-2), 109-123. DOI: 10.1016/S0167-9473(03)00030-6 
Figures and Tables

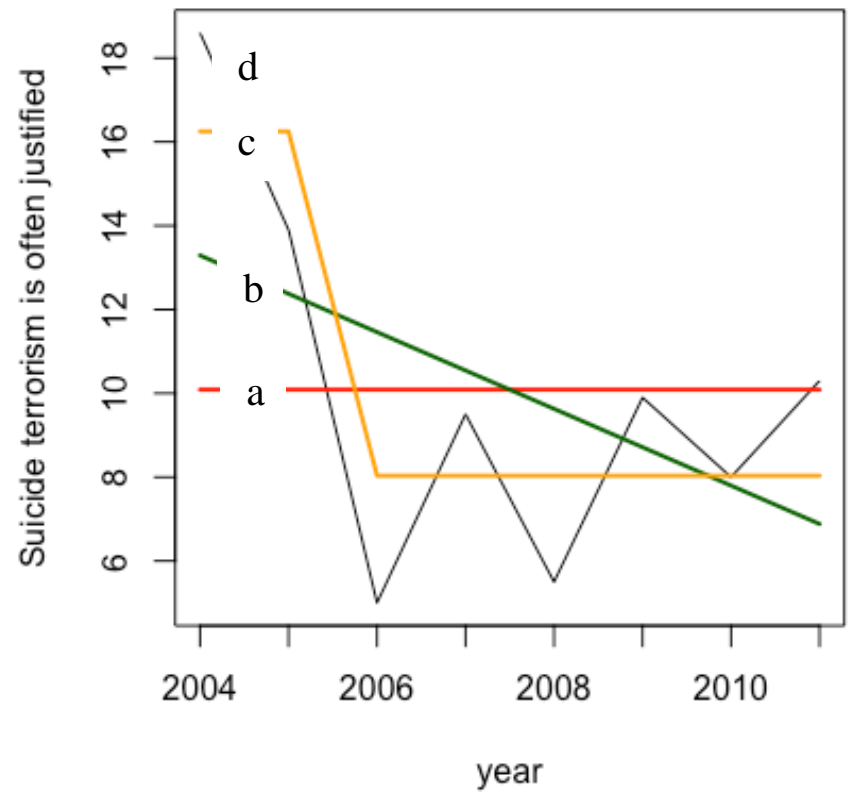

Figure 1. Plotting models against observed data 'often justified'.

Note: $\mathrm{a}=$ intercept-only model, $\mathrm{b}=$ linear trend model, $\mathrm{c}=$ breakpoint model, $\mathrm{d}=$ observed data 


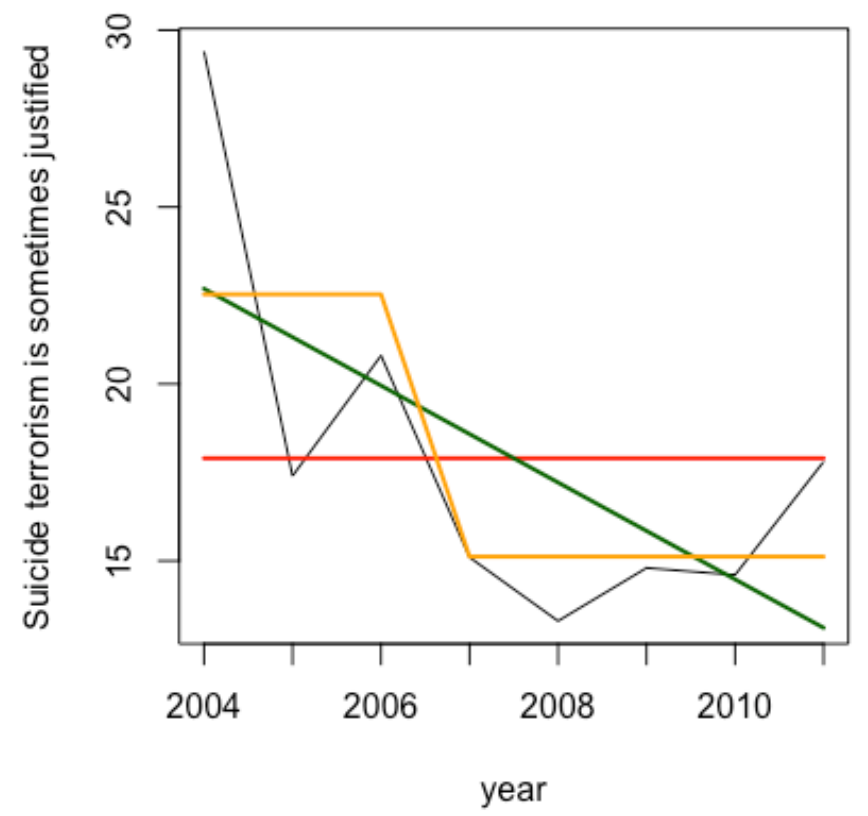

Figure 2. Plotting models against observed data 'sometimes justified'.

Note $: \mathrm{a}=$ intercept-only model, $\mathrm{b}=$ linear trend model, $\mathrm{c}=$ breakpoint model, $\mathrm{d}=$ observed data 


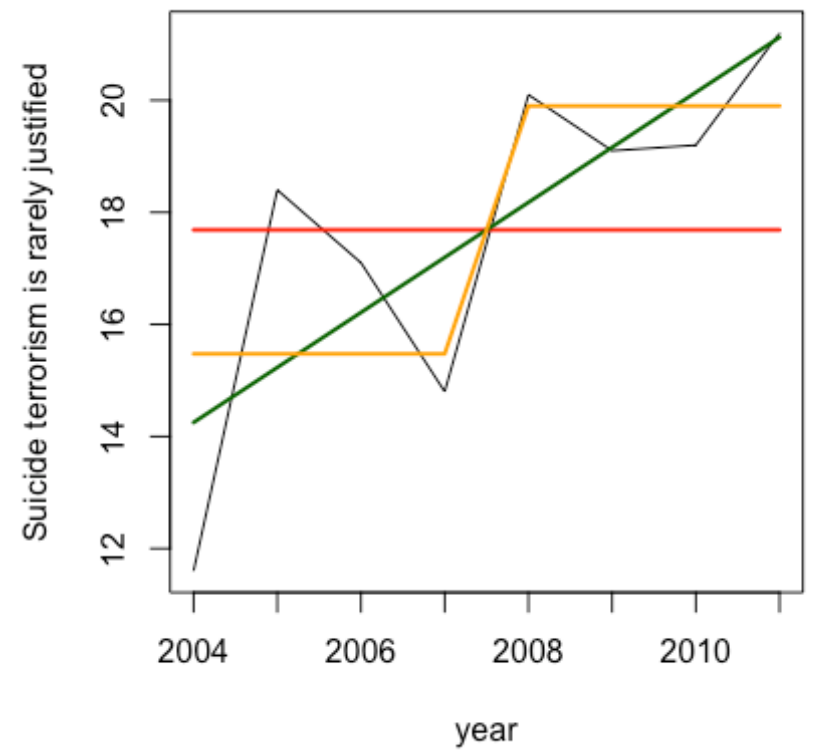

Figure 3. Plotting models against observed data 'rarely justified'.

Note: $\mathrm{a}=$ intercept-only model, $\mathrm{b}=$ linear trend model, $\mathrm{c}=$ breakpoint model, $\mathrm{d}=$ observed data 
Running head: Public Support for Terrorism Over Time

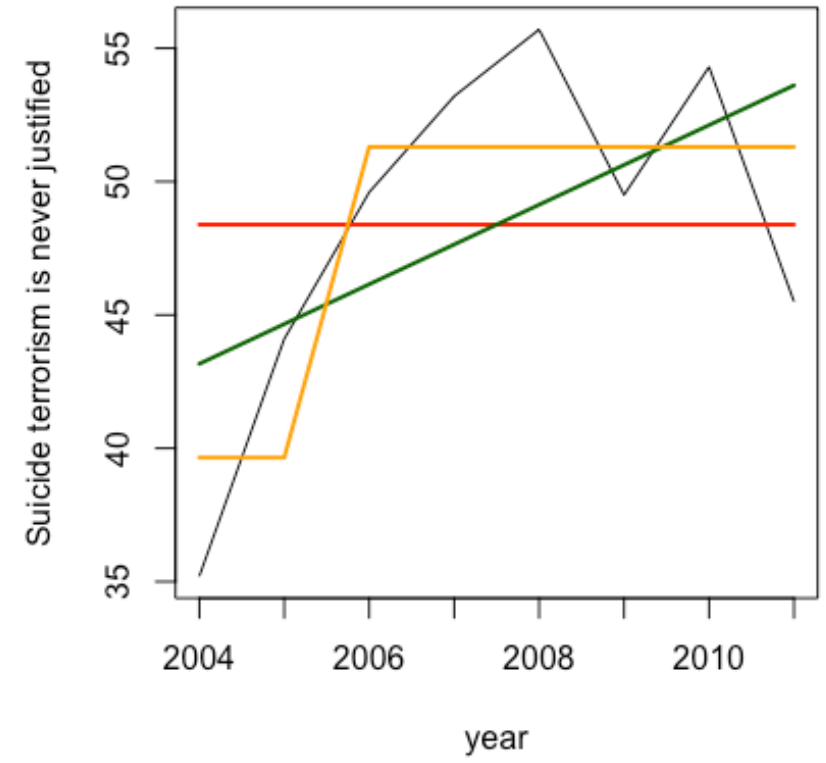

Figure 4. Plotting models against observed data 'never justified'.

Note: $\mathrm{a}=$ intercept-only model, $\mathrm{b}=$ linear trend model, $\mathrm{c}=$ breakpoint model, $\mathrm{d}=$ observed data 


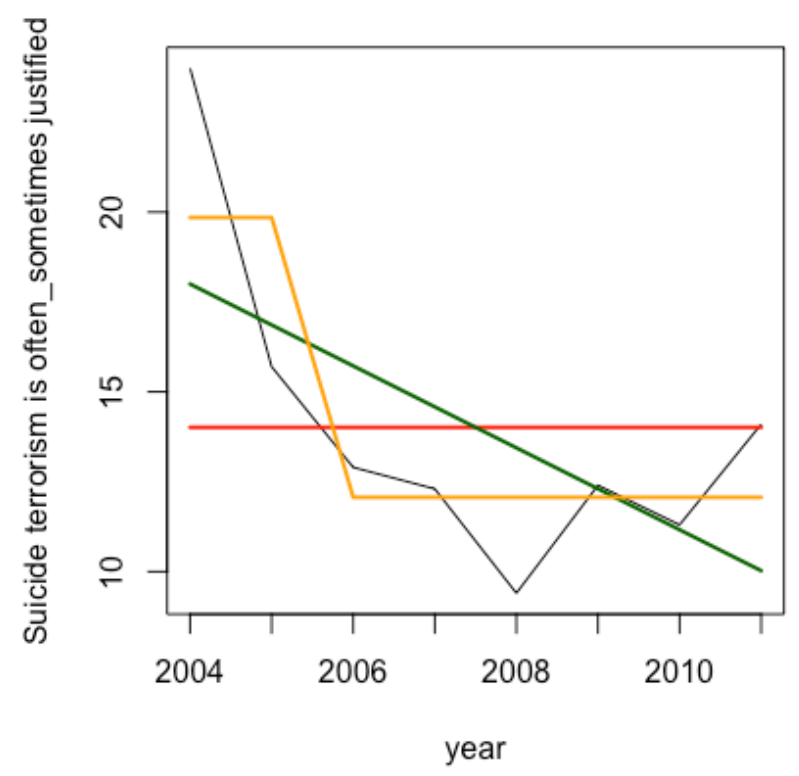

Figure 5. Plotting models against observed data 'often/sometimes (mean) justified'.

Note: $\mathrm{a}=$ intercept-only model, $\mathrm{b}=$ linear trend model, $\mathrm{c}=$ breakpoint model, $\mathrm{d}=$ observed data 


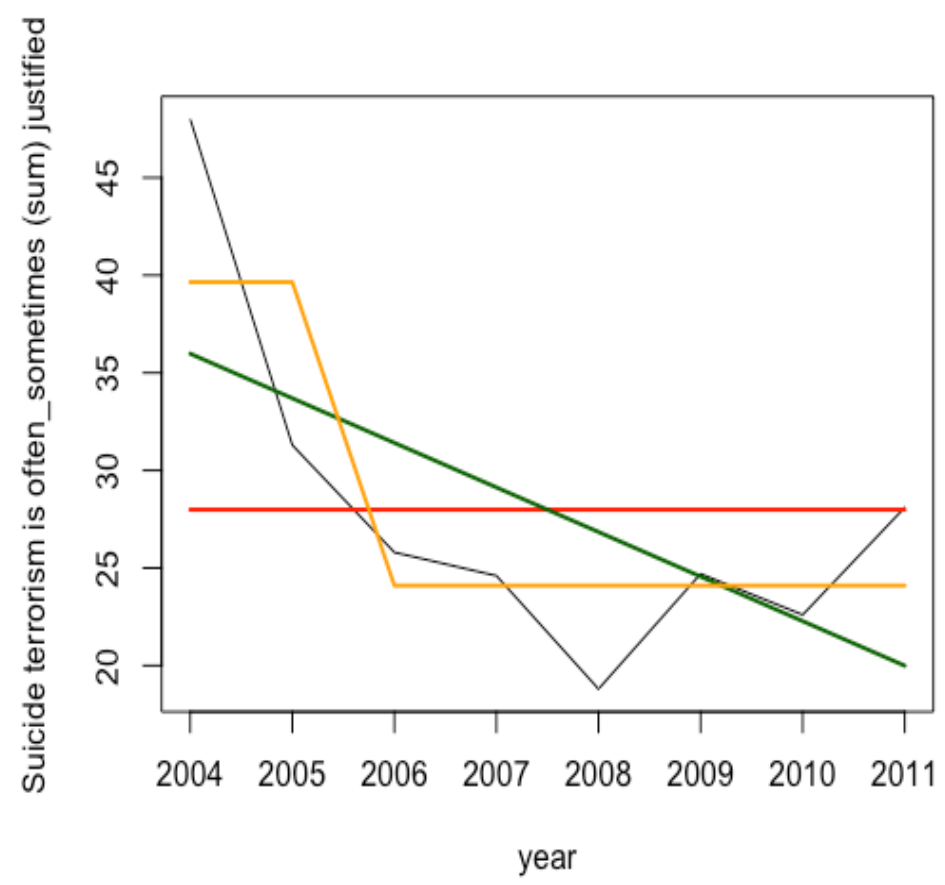

Figure 6. Plotting models against observed data 'often/sometimes (sum) justified'.

Note: $\mathrm{a}=$ intercept-only model, $\mathrm{b}=$ linear trend model, $\mathrm{c}=$ breakpoint model, $\mathrm{d}=$ observed data 


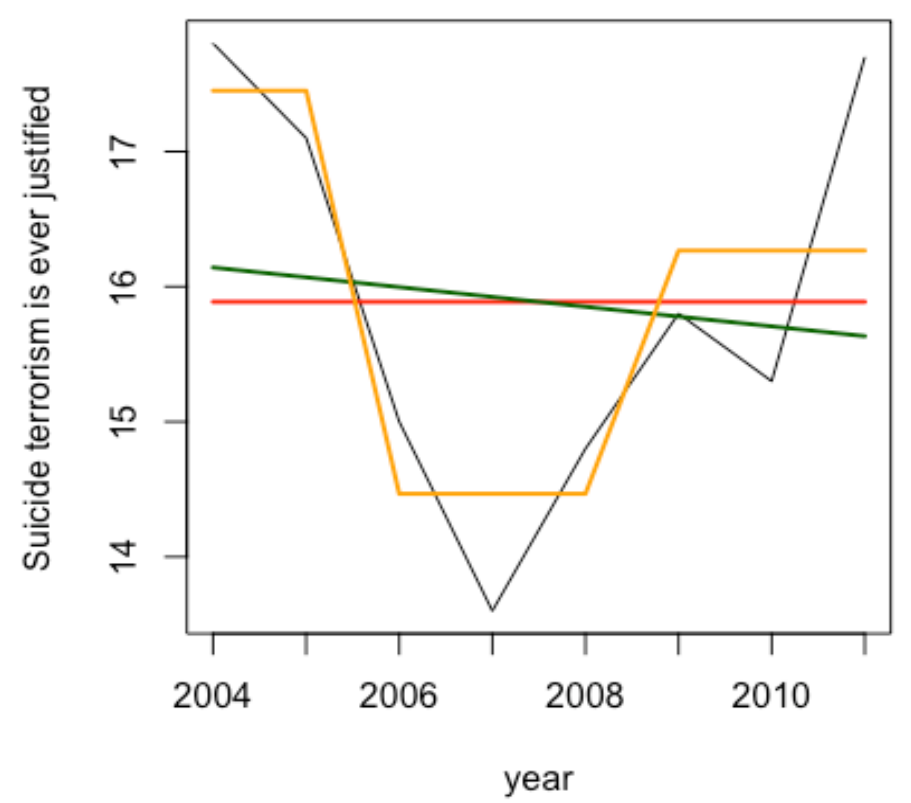

Figure 7. Plotting models against observed data 'ever (mean) justified'.

Note: $\mathrm{a}=$ intercept-only model, $\mathrm{b}=$ linear trend model, $\mathrm{c}=$ breakpoint model, $\mathrm{d}=$ observed data 


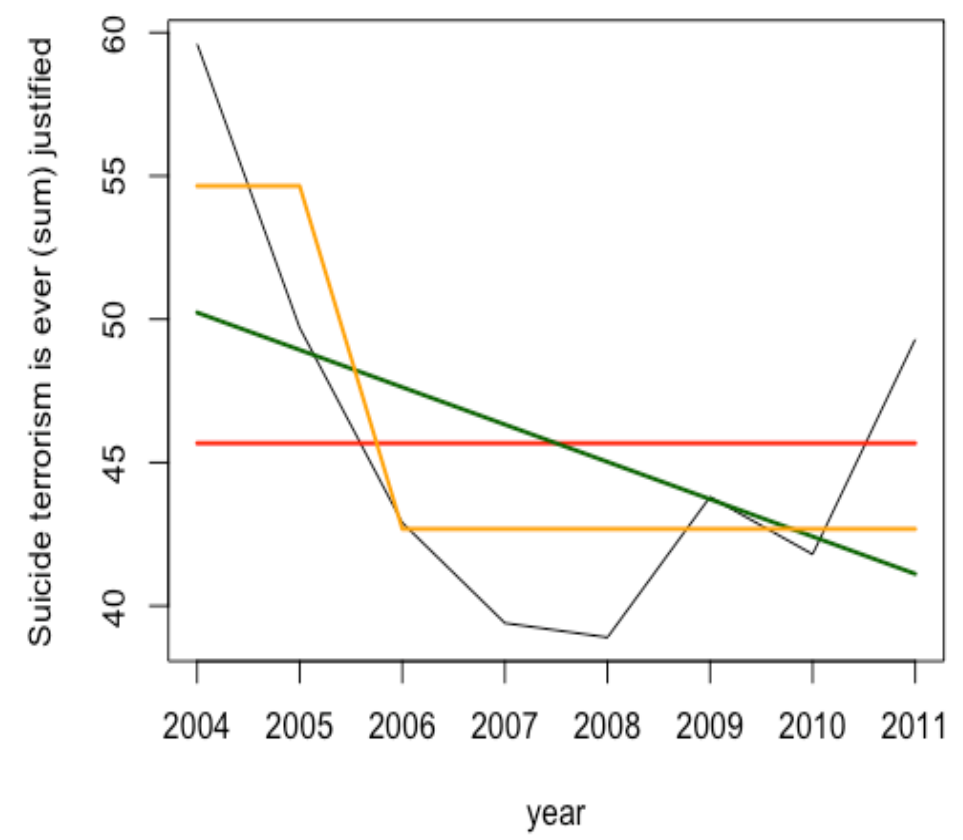

Figure 8. Plotting models against observed data 'ever (sum) justified'.

Note: $\mathrm{a}=$ intercept-only model, $\mathrm{b}=$ linear trend model, $\mathrm{c}=$ breakpoint model, $\mathrm{d}=$ observed data 
Table 1. Overview of included countries, sample size, location of data collection, fieldwork period, sampling error and response rate.

\begin{tabular}{|c|c|c|c|c|c|c|c|c|c|}
\hline Country & & 2004 & 2005 & 2006 & 2007 & 2008 & 2009 & 2010 & 2011 \\
\hline \multirow[t]{2}{*}{ Jordan } & $\begin{array}{l}N \\
\text { Geographic } \\
\text { regions }\end{array}$ & $\begin{array}{l}1000 \\
\text { not provided }\end{array}$ & $\begin{array}{l}1000 \\
\text { North } N=280, \\
\text { Center } N=600 \text {, } \\
\text { South } N=120\end{array}$ & $\begin{array}{l}2000 \\
\text { North } N=560, \\
\text { Center } N=1200 \\
\text { South } N=240\end{array}$ & $\begin{array}{l}1000 \\
\text { North } N=233, \\
\text { Center } N=624, \\
\text { South } N=143\end{array}$ & $\begin{array}{l}1000 \\
\text { North } N=242, \\
\text { Center } N=622, \\
\text { South } N=136\end{array}$ & $\begin{array}{l}1000 \\
\text { North } N=240, \\
\text { Center } N=632 \\
\text { South } N=128\end{array}$ & $\begin{array}{l}1000 \\
\text { North } N=244, \\
\text { Center } N=625, \\
\text { South } N=131\end{array}$ & $\begin{array}{l}2000 \\
\text { North } N=464, \\
\text { Center } N=1262 \\
\text { South } N=274\end{array}$ \\
\hline & $\begin{array}{l}\text { Fieldwork period } \\
\text { Sampling error } \\
\text { Response rate* }\end{array}$ & $\begin{array}{l}24.2 .-29.2 . \\
3.5 \% \\
.99\end{array}$ & $\begin{array}{l}3.5 .-24.5 . \\
3 \% \\
.52\end{array}$ & $\begin{array}{l}5.4 .-27.4 . \\
3 \% \\
.97\end{array}$ & $\begin{array}{l}9.4 .-7.5 \\
3 \% \\
.92\end{array}$ & $\begin{array}{l}18.3 .-6.4 . \\
3 \% \\
.97\end{array}$ & $\begin{array}{l}24.5 .-11.6 . \\
3 \% \\
.96\end{array}$ & $\begin{array}{l}12.4 .-3.5 . \\
4 \% \\
.97\end{array}$ & $\begin{array}{l}21.3 .-7.4 . \\
4 \% \\
.97\end{array}$ \\
\hline Turkey & $\begin{array}{l}N \\
\text { Geographic } \\
\text { region }\end{array}$ & $\begin{array}{l}1017 \\
\text { Metropolitan } \\
\text { cities } N=280, \\
\text { Marmara } N= \\
122, \text { Aegean } N \\
=88, \\
\text { Mediterranean } \\
N=133, \\
\text { Central } \\
\text { Anatolia } N= \\
110, \text { Black } \\
\text { Sea } N=127, \\
\text { Eastern } \\
\text { Anatolia } N= \\
78, \\
\text { Southeastern } \\
N=79\end{array}$ & $\begin{array}{l}1003 \\
\text { Metropolitan } \\
\text { cities } N=277, \\
\text { Marmara } N= \\
123, \text { Aegean } N \\
=87, \\
\text { Mediterranean } \\
N=109, \text { Middle } \\
\text { Anatolia } N= \\
127, \text { Black Sea } \\
N=125, \\
\text { Eastern Anatolia } \\
N=79, \\
\text { Southeastern } N \\
=76\end{array}$ & $\begin{array}{l}2026 \\
\text { Metropolitan } \\
\text { cities } N=572, \\
\text { Marmara } N=242, \\
\text { Aegean } N=176, \\
\text { Mediterranean } N \\
=254, \text { Middle } \\
\text { Anatolia } N=220, \\
\text { Black Sea } N= \\
\text { 256, Eastern } \\
\text { Anatolia } N=154, \\
\text { Southeastern } N= \\
\text { 152 }\end{array}$ & $\begin{array}{l}971 \\
\text { Metropolitan } \\
\text { cities } N=255, \\
\text { Marmara } N= \\
129, \text { Aegean } N \\
=86, \\
\text { Mediterranean } \\
N=128, \text { Middle } \\
\text { Anatolia } N= \\
105, \text { Black Sea } \\
N=107, \\
\text { Eastern Anatolia } \\
N=81, \\
\text { Southeastern } N \\
=81\end{array}$ & $\begin{array}{l}1003 \\
\text { Istanbul } N= \\
161, \text { Tekirdag } N \\
=22, \text { Balikesir } \\
N=25, \text { Izmir } N \\
=54, \text { Aydin } N= \\
38, \text { Manisa } N= \\
47, \text { Bursa } N= \\
47, \text { Kocaeli } N= \\
42, \text { Ankara } N= \\
63, \text { Konya } N= \\
35, \text { Antalya } N= \\
40, \text { Adana } N= \\
50, \text { Hatay } N= \\
38, \text { Kýrýkkale } N \\
=24, \text { Kayseri } N \\
=36, \text { Zonguldak } \\
N=16, \\
\text { Kastamonu } N= \\
13, \text { Samsun } N= \\
44, \text { Trabzon } N= \\
47, \text { Erzurum } N \\
=19, \text { Aðrý } N= \\
15, \text { Malatya } N= \\
25, \text { Van } N=22, \\
\text { Gaziantep } N= \\
27, \text { Diyarbakýr } \\
N=33, \text { Mardin } \\
N=20 \\
\end{array}$ & $\begin{array}{l}1005 \\
\text { Istanbul } N= \\
\text { 186, Tekirdag } N \\
=23, \text { Balikesir } \\
N=25, \text { Izmir } N \\
=58, \text { Aydin } N= \\
40, \text { Manisa } N= \\
44, \text { Bursa } N= \\
51, \text { Kocaeli } N= \\
45, \text { Ankara } N= \\
68, \text { Konya } N= \\
31, \text { Antalya } N= \\
37, \text { Adana } N= \\
51, \text { Hatay } N= \\
38, \text { Kýrýkkale } N \\
=21, \text { Kayseri } N \\
=32, \text { Zonguldak } \\
N=16, \\
\text { Kastamonu } N= \\
11, \text { Samsun } N= \\
40, \text { Trabzon } N= \\
\text { 37, Erzurum } N \\
=14, \text { Aðrý } N= \\
14, \text { Malatya } N= \\
22, \text { Van } N=21, \\
\text { Gaziantep } N= \\
28, \text { Diyarbakýr } \\
N=33, \text { Mardin } \\
N=20 \\
\end{array}$ & $\begin{array}{l}1003 \\
\text { Istanbul } N= \\
185, \text { Tekirdag } N \\
=23, \text { Balikesir } \\
N=25, \text { Izmir } N \\
=59, \text { Aydin } N= \\
41, \text { Manisa } N= \\
43, \text { Bursa } N= \\
\text { 52, Kocaeli } N= \\
45, \text { Ankara } N= \\
69, \text { Konya } N= \\
30, \text { Antalya } N= \\
38, \text { Adana } N= \\
50, \text { Hatay } N= \\
38, \text { Kýrýkkale } N \\
=21, \text { Kayseri } N \\
=32, \text { Zonguldak } \\
N=16, \\
\text { Kastamonu } N= \\
11, \text { Samsun } N= \\
41, \text { Trabzon } N= \\
33, \text { Erzurum } N \\
=14, \text { Aðrý } N= \\
14, \text { Malatya } N= \\
21, \text { Van } N=21, \\
\text { Gaziantep } N= \\
28, \text { Diyarbakýr } \\
N=33, \text { Mardin } \\
N=21\end{array}$ & $\begin{array}{l}2000 \\
\text { Istanbul } N=370, \\
\text { Tekirdag } N=46, \\
\text { Balikesir } N=50, \\
\text { Izmir } N=112, \\
\text { Aydin } N=78, \\
\text { Manisa } N=84, \\
\text { Bursa } N=104, \\
\text { Kocaeli } N=90, \\
\text { Ankara } N=136, \\
\text { Konya } N=60, \\
\text { Antalya } N=76, \\
\text { Adana } N=100, \\
\text { Hatay } N=76, \\
\text { Kýrýkkale } N= \\
42, \text { Kayseri } N= \\
64, \text { Zonguldak } N \\
=32, \text { Kastamonu } \\
N=22, \text { Samsun } N \\
=84, \text { Trabzon } N= \\
66, \text { Erzurum } N= \\
28, \text { Adrý } N=26, \\
\text { Malatya } N=42, \\
\text { Van } N=42, \\
\text { Gaziantep } N=62, \\
\text { Diyarbakýr } N= \\
66, \text { Mardin } N=42\end{array}$ \\
\hline
\end{tabular}


Fieldwork period Sampling error

Response rate*

21.2.-1.3.

$3.5 \%$

.99

$N$

$N$ per geographic

region

Fieldwork period

Sampling error

Response rate*

\section{Lebanon $N$}

$N$ per geographic

region

$\begin{array}{ll}27.4 .-14.5 . & 1.4 .-25.4 . \\ 3 \% & 3 \% \\ .48 & .98\end{array}$

98

1022

Java $N=672$,

Sumatra $N=$

204, Sulawesi $=$

84, Kalimantan

$N=21$, Bali $/$

Nusa Tenggara

$N=41$

30.4.-16.5

$3 \%$

48

1000

West Beirut $N=$

270, East Beirut

$N=280$, North

$N=140$, South

$N=130$, Beka

$N=100$, Mount

Lebanon $N=80$

.89
$2044-1008-1000$

Java $N=1262, \quad$ Java $N=645$,

Sumatra $N=$

Sumatra $N=454$

221, Sulawesi

Sulawesi $=120$

60, Kalimantan

$N=42$, Bali

82 , Bali/ Nusa

Nusa Tenggara

$N=40$

18.4.-28.4

$3 \%$

92

1000

see year 2005

West Beirut $N=$

272, East Beirut

$N=281$, North

$N=138$, South

$N=127$, Bekaa

$N=101$, Mount

Lebanon $N=81$

West Beirut $N=$

260, East Beirut

$N=282$, North

$N=145$, South

$N=126$, Bekaa

$N=108$, Mount

Lebanon $N=79$
Fieldwork period

Sampling error

Response rate*
3.5.-24.5.

.29
9.4.-7.5.

$3 \%$

.62
19.3.-7.4.

$3 \%$

.62

$\begin{array}{ll}12.4 .-30.4 . & 21.3 .-12.4 . \\ 4 \% & 4 \% \\ 97 & 92\end{array}$

.97

1000

Java $N=640$,

Sumatra $N=$

220, Sulawesi $=\quad$ Sulawesi $=122$

60, Kalimantan Kalimantan $N=$

$N=40$, Bali/

70 , Bali/ Nusa

Tenggara $N=80$

$N=40$

$\begin{array}{ll}16.4 .-29.4 . & 23.3 .-6.4 . \\ 4 \% & 4 \% \\ .90 & .88\end{array}$

90

1000

see year 2005

2000

West Beirut $N=$

150, East Beirut $N$

$=120$, North $N=$

430, South $N=$

180 , Bekaa $N=$

260, Mount

Lebanon $N=740$,

Nabatiyye $N=$

120

21.3.-7.4

.55 


\begin{tabular}{|c|c|c|c|c|c|c|c|}
\hline \multirow[t]{2}{*}{ Egypt } & $\begin{array}{l}N \\
N \text { per geographic } \\
\text { region }\end{array}$ & $\begin{array}{l}2000 \\
\text { Center (Cairo \& } \\
\text { Giza) } N=1100, \\
\text { West (Alexandria) } \\
N=400, \text { North } \\
\text { (Dakahlia \& } \\
\text { Gharbia) } N=260, \\
\text { South (Kalyoubia } \\
\& \text { Asyut) } N=240\end{array}$ & $\begin{array}{l}1000 \\
\text { Cairo } N=400, \\
\text { Alexandria } N= \\
200, \text { Dakahlia } N \\
=70, \text { Kalyoubia } \\
N=80, \text { The } \\
\text { Western } N=60, \\
\text { Giza } N=150, \\
\text { Asyut } N=40\end{array}$ & $\begin{array}{l}1000 \\
\text { Cairo } N=401, \\
\text { Alexandria } N= \\
200, \text { Dakahlia } N \\
=70, \text { Kalyoubia } \\
N=80, \text { The } \\
\text { Western } N=60, \\
\text { Giza } N=150, \\
\text { Asyut } N=39\end{array}$ & $\begin{array}{l}1000 \\
\text { North } N=130, \\
\text { West } N=200, \\
\text { Center } N=551, \\
\text { South } N=119\end{array}$ & $\begin{array}{l}1000 \\
\text { North } N=133 \\
\text { West } N=201, \\
\text { Center } N=542, \\
\text { South } N=124\end{array}$ & $\begin{array}{l}2000 \\
\text { Alexandria } N= \\
124, \text { Aswan } N= \\
40, \text { Asyut } N=98, \\
\text { Beheira } N=122, \\
\text { Beni Suef } N=60, \\
\text { Cairo } N=186, \\
\text { Dakahlia } N=138, \\
\text { Damietta } N=20, \\
\text { Fayoum } N=78, \\
\text { Gharbia } N=122, \\
\text { Giza } N=74, \\
\text { Helwan } N=44, \\
\text { Ismailia } N=20, \\
\text { Kafr el-Sheikh } N \\
=84, \text { Luxor } N= \\
\text { 28, Minya } N= \\
116, \text { Monufia } N= \\
\text { 92, Port Said } N= \\
\text { 18, Qalyubia } N= \\
116, \text { Qena } N=78, \\
\text { Sharqia } N=142, \\
\text { Sohag } N=94, \\
\text { Suez } N=24, \\
\text { October } 6 N=82\end{array}$ \\
\hline & $\begin{array}{l}\text { Fieldwork period } \\
\text { Sampling error } \\
\text { Response rate* }\end{array}$ & $\begin{array}{l}5.4 .-27.4 . \\
3 \% \\
.93\end{array}$ & $\begin{array}{l}9.4 .-7.5 . \\
3 \% \\
.88\end{array}$ & $\begin{array}{l}19.3 .-3.4 . \\
3 \% \\
.90\end{array}$ & $\begin{array}{l}24.5 .-11.6 . \\
3 \% \\
.94\end{array}$ & $\begin{array}{l}12.4 .-3.5 . \\
4 \% \\
.94\end{array}$ & $\begin{array}{l}24.3 .-7.4 . \\
4 \% \\
.94\end{array}$ \\
\hline Nigeria & $\begin{array}{l}N \\
N \text { per geographic } \\
\text { region }\end{array}$ & $\begin{array}{l}2000 \\
\text { North West } N= \\
514, \text { North East } N \\
=270, \text { North } \\
\text { Central } N=280, \\
\text { South West } N= \\
392, \text { South East } N \\
=244, \text { South } \\
\text { South } N=300\end{array}$ & $\begin{array}{l}1128 \\
\text { North West } N= \\
260, \text { North East } \\
N=226, \text { North } \\
\text { Central } N=124 \text {, } \\
\text { South West } N= \\
262, \text { South East } \\
N=208, \text { South } \\
\text { South } N=148\end{array}$ & $\begin{array}{l}1000 \\
\text { North West } N= \\
226, \text { North East } \\
N=175, \text { North } \\
\text { Central } N=125, \\
\text { South West } N= \\
246, \text { South East } \\
N=104, \text { South } \\
\text { South } N=124\end{array}$ & $\begin{array}{l}1000 \\
\text { North West } N= \\
259, \text { North East } \\
N=147, \text { North } \\
\text { Central } N=106, \\
\text { South West } N= \\
252, \text { South East } \\
N=108, \text { South } \\
\text { South } N=128\end{array}$ & $\begin{array}{l}1000 \\
\text { North West } N= \\
260, \text { North East } \\
N=132, \text { North } \\
\text { Central } N=148, \\
\text { South West } N= \\
132, \text { South East } \\
N=116, \text { South } \\
\text { South } N=148, \\
\text { Lagos } N=64\end{array}$ & \\
\hline
\end{tabular}


Fieldwork period

Sampling error

Response rate*

$N$ per geographic

region

Fieldwork period

Sampling error

Response rate*

Ethiopia $\quad N$

$N$ per geographic

region

Fieldwork period

Sampling error

Response rate*

Israel

$N$ per geographic
region
20.4.-29.4.

.47

23.4.-29.5

$3 \%$

.76

8.4.-21.4.

$3 \%$

.42

2.6.-14.6.

$3 \%$

.53

18.4.-7.5.

$4 \%$

1000

Dhaka $N=291$,

Chittagong $N=$

174 , Khulna $N=$

152, Rajshahi $N$

$=246$, Barisal $N$

$=80$, Sylhet $N=$

57

11.4.-30.4.

$3 \%$

89

710

Adis Abeba $N=$

430, Amara $N=$

77, Dire Dawa

$\mathrm{N}=44$, Hareri

Hizb N = 43,

Oromiya $N=$

93, Southern $N$

$=23$

27.4.-7.5.

$4 \%$

.32
1201

Jerusalem $N=$

93, North $N=$

205, Haifa $N=$

180 , Center $N=$

300, Tel Aviv $N$

$=266$, South $N$

$=158$
1814

Jerusalem $N=$

100, North $N=$

560, Haifa $N=$

296, Center $N=$

378, Tel Aviv $N=$

300 , South $N=$

180 
Fieldwork period

Sampling error

Response rate*

Senegal

$N$ per geographic

region

Fieldwork period

Sampling error

Response rate*

Tanzania

$N$

$N$ per geographic

region

700

Dakar $N=185$,

Matam $N=40$,

Diourbel $N=$

135, Saint-Louis

$N=105$,

Tambacouda $N$

$=50$, Kaolack $N$

$=85$, Thies $N=$

100

14.4.-19.4.

$4 \%$

.97

704

Arusha $N=24$

Dar es salaam $N$

= 47, Dodoma $N$

$=33$, Iringa $N=$

32 , Kagera $N=$

40 , Kigoma $N=$

32, Kilimanjaro

$N=32$, Lindi $N$

$=16$, Manyara

$N=24$, Mara $N$

$=32$, Mbeya $N$

$=40$, Morogoro

$N=40$, Mwanza

$N=56$, Mtwara

$N=24$, Pwani $N$

$=16$, Rukwa $N$

$=24$, Ruvuma $N$

$=24$, Singida $N$

$=24$, Shinyanga

$N=56$, Tabora

$N=32$, Tanga $N$ 
$=32$, Unguja $N$

= 16, Pemba $N$

$=8$

Fieldwork period

Sampling error

21.4.-14.5.

Response rate*

$4 \%$

.35

Kuwait

$N$

$N$ per geographic

region

500

Capital $N=83$,

Hawally $N=$

167, Farwaniya

$N=106$,

Ahmadi $N=73$,

Jahra $N=32$,

Mubarak Al

Kabeer $N=39$

Fieldwork period

Sampling error

15.4.-10.5

Response rate*

$4 \%$

.94

\section{$\operatorname{Morocco}^{* *} \quad N$}

$N$ per geographic

region

1000

Casa $N=121$,

Rabat $N=79$,

Chaouia $N=55$,

Doukala $N=66$,

Gharb $N=62$,

Marrakech $N=$

104, Tadla $N=$

49 , Fès $N=53$,

Meknès $N=71$,

Tanger $N=81$,

Taza $N=62$,

Oriental $N=65$,

Souss $N=132$

Fieldwork period

20.4.-10.5.

Sampling error

$3 \%$

Response rate* 


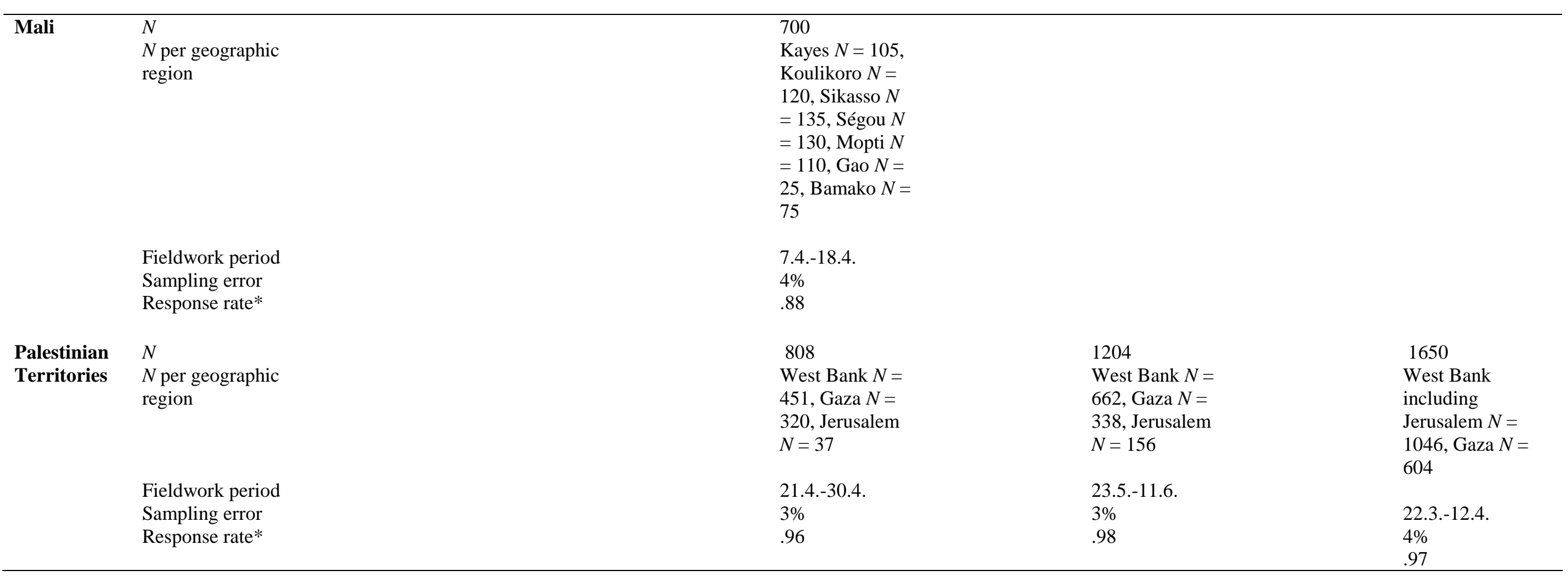

Note.

* Response Rate 1, the minimum response rate for the item assessing support for suicide terrorism

**Waves before 2007 were excluded as the sample was primarily urban 
Table 2. Public support for terrorism, average across all countries/per wave, considering distinct operationalisations of public opinion.

\begin{tabular}{lllllllll}
\hline $\begin{array}{l}\text { Operationalisation } \\
\text { of public opinion }\end{array}$ & $\mathbf{2 0 0 4}$ & $\mathbf{2 0 0 5}$ & $\mathbf{2 0 0 6}$ & $\mathbf{2 0 0 7}$ & $\mathbf{2 0 0 8}$ & $\mathbf{2 0 0 9}$ & $\mathbf{2 0 1 0}$ & $\mathbf{2 0 1 1}$ \\
\hline Often justified & $18.6 \%$ & $13.9 \%$ & $5 \%$ & $9.5 \%$ & $5.5 \%$ & $9.9 \%$ & $8 \%$ & $10.3 \%$ \\
Sometimes justified & $29.4 \%$ & $17.4 \%$ & $20.8 \%$ & $15.1 \%$ & $13.3 \%$ & $14.8 \%$ & $14.6 \%$ & $17.8 \%$ \\
Rarely justified & $11.6 \%$ & $18.4 \%$ & $17.1 \%$ & $14.8 \%$ & $20.1 \%$ & $19.1 \%$ & $19.2 \%$ & $21.2 \%$ \\
$\begin{array}{l}\text { Never justified } \\
\text { S5.2\% }\end{array}$ & $44.1 \%$ & $49.6 \%$ & $53.2 \%$ & $55.7 \%$ & $49.5 \%$ & $54.3 \%$ & $45.5 \%$ \\
$\begin{array}{l}\text { Often/Sometimes } \\
\text { justified (mean) }\end{array}$ & $24 \%$ & $15.7 \%$ & $12.9 \%$ & $12.3 \%$ & $9.4 \%$ & $12.4 \%$ & $11.3 \%$ & $14.1 \%$ \\
$\begin{array}{l}\text { Often/Sometimes } \\
\text { justified (sum) }\end{array}$ & $48 \%$ & $31.3 \%$ & $25.8 \%$ & $24.6 \%$ & $18.8 \%$ & $24.7 \%$ & $22.6 \%$ & $28.1 \%$ \\
$\begin{array}{l}\text { Ever justified } \\
\text { (mean) }\end{array}$ & $17.8 \%$ & $17.1 \%$ & $15 \%$ & $13.6 \%$ & $14.8 \%$ & $15.8 \%$ & $15.3 \%$ & $17.7 \%$ \\
$\begin{array}{l}\text { Ever justified (sum) } \\
59.6 \%\end{array}$ & $49.7 \%$ & $42.9 \%$ & $39.4 \%$ & $38.9 \%$ & $43.8 \%$ & $41.8 \%$ & $49.3 \%$ \\
\hline
\end{tabular}

Note. Values are rounded and may not add up to $100 \%$ 
Table 3. Model fit for all operationalisations of public support for terrorism.

\begin{tabular}{|c|c|c|c|c|c|}
\hline Outcome & Model & AIC & BIC & MAE & RMSE \\
\hline \multirow[t]{3}{*}{ Often justified } & Stationary & 49.53 & 49.69 & 3.13 & 4.16 \\
\hline & Linear & 49.18 & 49.42 & 2.91 & 3.60 \\
\hline & Breakpoint (1) & 41.05 & 41.29 & 1.99 & 2.16 \\
\hline \multirow{3}{*}{$\begin{array}{l}\text { Sometimes } \\
\text { justified }\end{array}$} & Stationary & 52.06 & 52.22 & 3.60 & 4.88 \\
\hline & Linear & 49.79 & 50.03 & 3.09 & 3.74 \\
\hline & Breakpoint (1) & 47.83 & 48.06 & 2.39 & 3.30 \\
\hline \multirow[t]{3}{*}{ Rarely justified } & Stationary & 43.90 & 44.06 & 2.39 & 2.93 \\
\hline & Linear & 38.78 & 39.01 & 1.51 & 1.88 \\
\hline & Breakpoint (1) & 39.15 & 39.39 & 1.51 & 1.92 \\
\hline \multirow[t]{3}{*}{ Never justified } & Stationary & 56.09 & 56.25 & 5.09 & 6.27 \\
\hline & Linear & 55.27 & 55.51 & 4.44 & 5.26 \\
\hline & Breakpoint (1) & 49.76 & 50.01 & 3.44 & 3.71 \\
\hline \multirow{3}{*}{$\begin{array}{l}\text { Often/sometimes } \\
\text { justified (mean) }\end{array}$} & Stationary & 49.49 & 49.64 & 2.94 & 4.15 \\
\hline & Linear & 47.47 & 47.70 & 2.58 & 3.23 \\
\hline & Breakpoint (1) & 42.89 & 43.13 & 1.90 & 2.43 \\
\hline \multirow{3}{*}{$\begin{array}{l}\text { Often/sometimes } \\
\text { justified (sum) }\end{array}$} & Stationary & 60.58 & 60.73 & 5.86 & 8.31 \\
\hline & Linear & 58.53 & 58.77 & 5.15 & 6.45 \\
\hline & Breakpoint (1) & 54.01 & 54.25 & 3.79 & 4.86 \\
\hline \multirow{3}{*}{$\begin{array}{l}\text { Ever justified } \\
\text { (mean) }\end{array}$} & Stationary & 32.23 & 32.39 & 1.23 & 1.41 \\
\hline & Linear & 34.12 & 34.36 & 1.19 & 1.40 \\
\hline & Breakpoint (2) & 26.27 & 26.59 & .66 & .76 \\
\hline \multirow{3}{*}{$\begin{array}{l}\text { Ever justified } \\
\text { (sum) }\end{array}$} & Stationary & 56.57 & 56.73 & 5.39 & 6.47 \\
\hline & Linear & 56.66 & 56.90 & 4.60 & 5.74 \\
\hline & Breakpoint (1) & 50.36 & 50.60 & 3.23 & 3.87 \\
\hline
\end{tabular}




\section{Appendix (for online supplementary material)}

\section{Code Script}

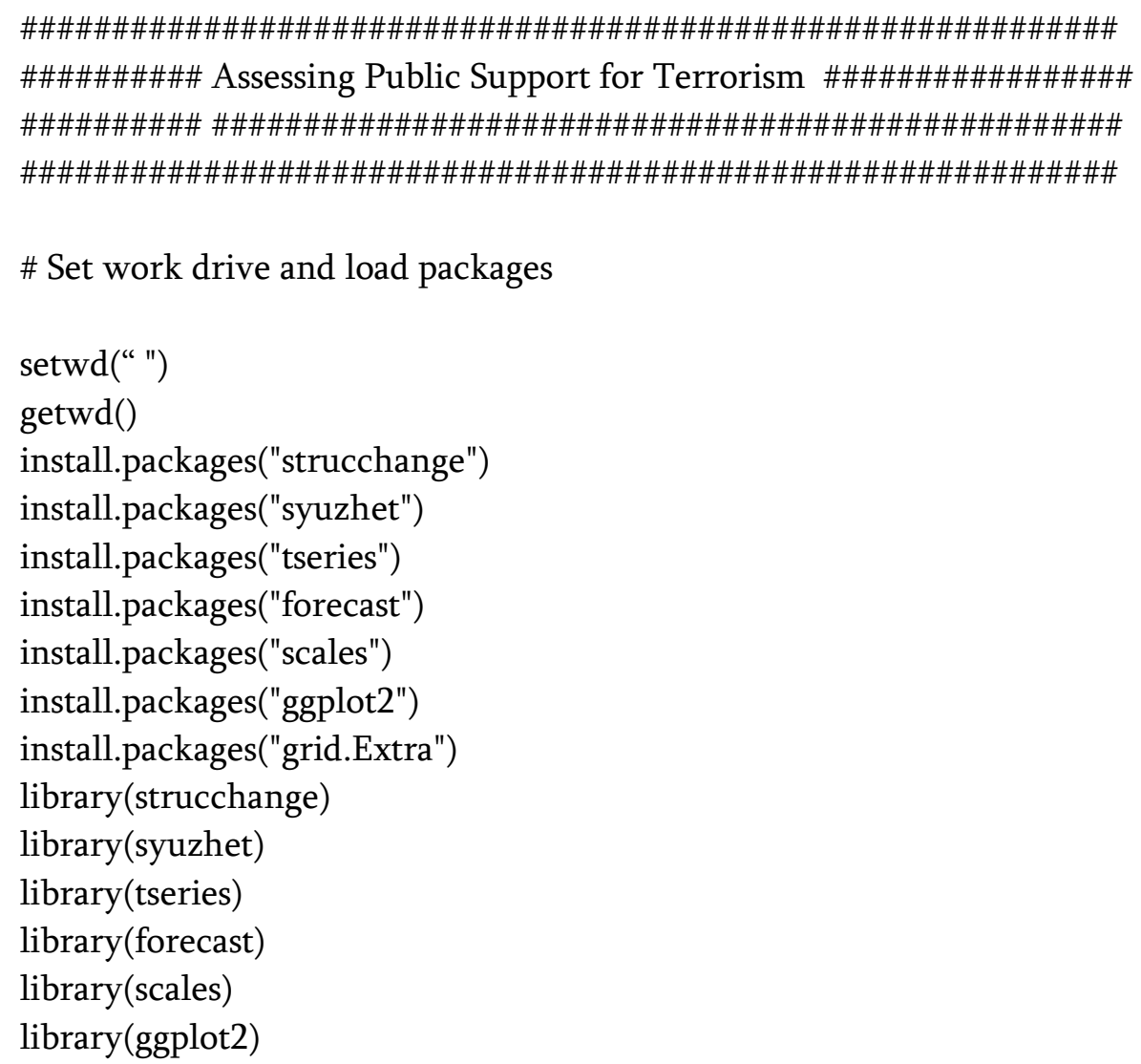

\#Create observed data

\#\#create data often waves $<-c(1,2,3,4,5,6,7,8)$ 
\#\#create data often_sometimes (mean)

waves $<-c(1,2,3,4,5,6,7,8)$

often_sometimes<-c $(24,15.7,12.9,12.3,9.4,12.4,11.3,14.1)$

data $<$-data.frame $($ Year $=$ waves, DV $=$ often_sometimes $)$

\#\#\#create data often_sometimes (sum)

waves $<-\mathrm{c}(1,2,3,4,5,6,7,8)$

os_sum $<-c(48,31.3,25.8,24.6,18.8,24.7,22.6,28.1)$

data $<$-data.frame $($ Year $=$ waves, $D V=$ os_sum $)$

\#\#create data ever (mean)

waves $<-c(1,2,3,4,5,6,7,8)$

ever $<-c(17.8,17.1,15,13.6,14.8,15.8,15.3,17.7)$

data $<$-data.frame $($ Year $=$ waves, $D V=$ ever $)$

\#\#\#create data ever (sum)

waves $<-\mathrm{c}(1,2,3,4,5,6,7,8)$

ever_sum $<-c(59.6,49.7,42.9,39.4,38.9,43.8,41.8,49.3)$

data $<$-data.frame $($ Year $=$ waves, DV $=$ ever_sum $)$

\# Plot observed data

\#\#plot data often

ts.often $=\operatorname{ts}($ data $=$ data $\$ D V$, start $=c(2004)$, end $=c(2011)$, frequency $=1)$

plot(ts.often, ylab = "Suicide terrorism is often justified")

\#\#plot data sometimes

ts.sometimes $=$ ts $($ data $=$ data $\$ D V$, start $=c(2004)$, end $=c(2011)$, frequency $=1)$

plot(ts.sometimes, ylab = "Suicide terrorism is sometimes justified")

\#\#plot data rarely

ts.rarely $=\mathrm{ts}($ data $=$ data $\$ D V$, start $=c(2004)$, end $=c(2011)$, frequency=1)

plot(ts.rarely, ylab = "Suicide terrorism is rarely justified")

\#\#plot data never

ts.never $=\mathrm{ts}($ data $=$ data\$DV, start $=\mathrm{c}(2004)$, end $=\mathrm{c}(2011)$, frequency $=1)$

plot(ts.never, ylab = "Suicide terrorism is never justified")

\#\#plot data often_sometimes (mean)

ts.often_sometimes $=\mathrm{ts}($ data $=$ data $\$ D V$, start $=c(2004)$, end $=c(2011)$, frequency $=1)$

plot(ts.often_sometimes, ylab = "Suicide terrorism is often/sometimes justified")

\#\#\#plot data often_sometimes (sum)

ts.os_sum $=\mathrm{ts}($ data $=$ data $\$ D V$, start $=c(2004)$, end $=c(2011)$, frequency $=1)$

plot(ts.os_sum, ylab = "Suicide terrorism is often_sometimes sum justified")

\#\#plot data ever (mean)

ts.ever $=\operatorname{ts}($ data $=$ data $\$ D V$, start $=c(2004)$, end $=c(2011)$, frequency $=1)$ 
plot(ts.ever, ylab = "Suicide terrorism is ever justified")

\#\#\#plot data ever (sum)

ts.ever_sum $=\operatorname{ts}($ data $=$ data $\$ D V$, start $=c(2004)$, end $=c(2011)$, frequency $=1)$

plot(ts.ever_sum, ylab = "Suicide terrorism is ever sum justified")

\#Fit models and plot breakpoints

\#\#Often

\#\#\#Stationary

adf.test (ts.often, alternative $=$ "stationary")

nochange_model $=\operatorname{lm}($ ts.often $\sim 1)$

AIC(nochange_model)

BIC(nochange_model)

logLik(nochange_model)

mean(abs(nochange_model\$residuals))

sqrt $\left(\right.$ mean(nochange_model\$residuals $\left.{ }^{\wedge} 2\right)$ )

\#\#\#Simple linear

linear_model $=\operatorname{lm}($ ts.often $\sim$ time $($ ts.often $))$

AIC(linear_model)

BIC(linear_model)

logLik(linear_model)

mean(abs(linear_model\$residuals))

sqrt(mean(linear_model\$residuals $\left.{ }^{\wedge} 2\right)$ )

\#\#\#Fixed breakpoints

bps1 = breakpoints(ts.often $\sim 1, \mathrm{~h}=2$ )

plot(bps1)

bfs1 = breakfactor(bps1, breaks = length (bps1\$breakpoints)

breakpoint_model $1=\operatorname{lm}($ ts.often $\sim$ bfs $1-1)$

AIC(breakpoint_model1)

BIC(breakpoint_model1)

logLik(breakpoint_model1)

mean(abs(breakpoint_model1\$residuals))

$\operatorname{sqrt}\left(\right.$ mean(breakpoint_model1\$residuals $\left.{ }^{\wedge} 2\right)$ )

\#\#\#Plot breakpoints

plot(ts.often, ylab = "Suicide terrorism is often justified", xlab = "year")

lines(ts(predict(nochange_model), start $=c(2004)$, end $=c(2011))$

, col='red'

, lwd $=2$ )

lines(ts(predict(linear_model), start $=\mathrm{c}(2004)$, end $=\mathrm{c}(2011))$

, col='darkgreen'

, lwd $=2$ )

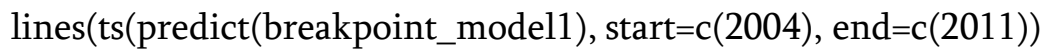

, col='orange'

, lwd $=2$ ) 


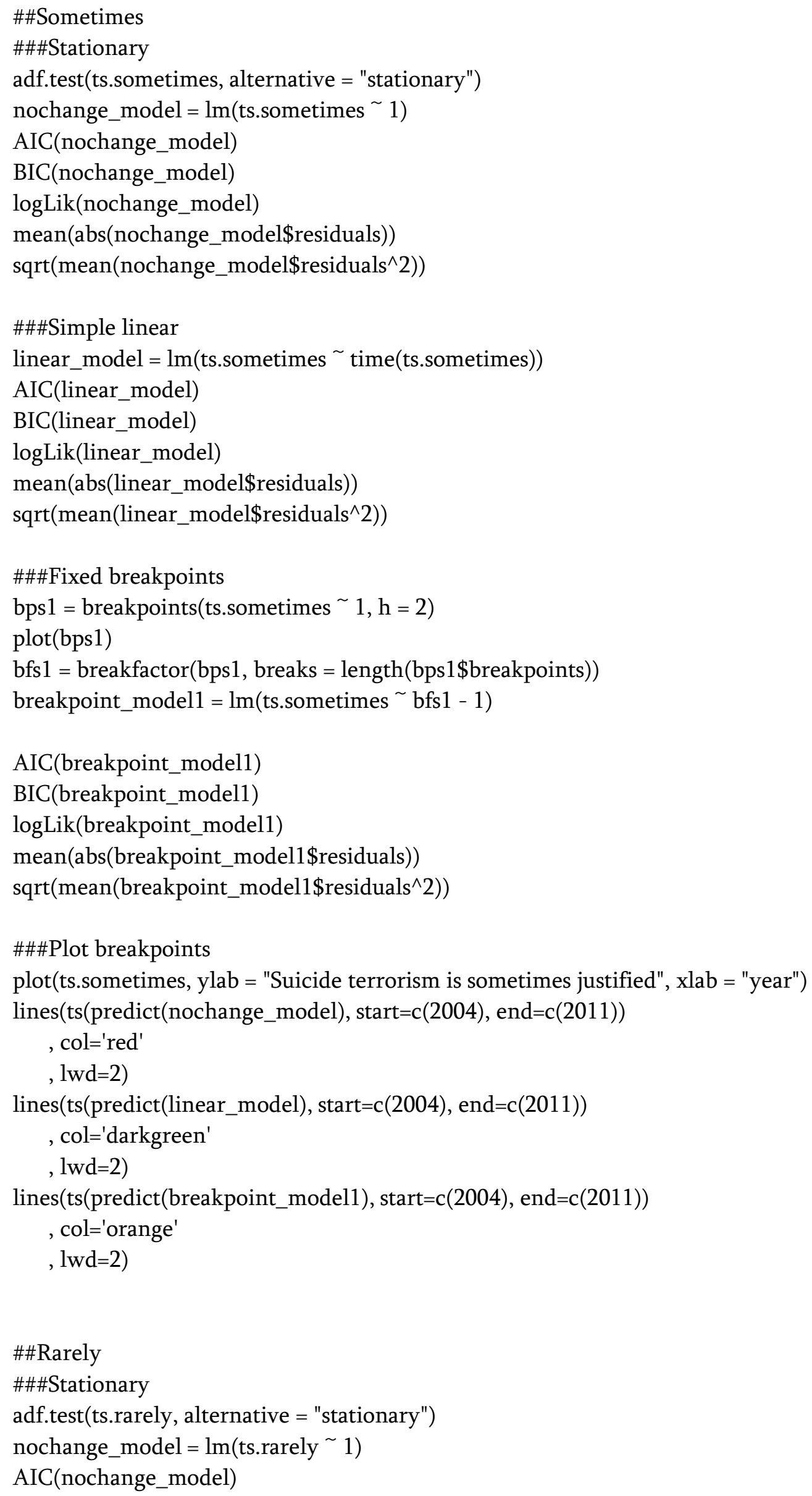


BIC(nochange_model)

$\operatorname{logLik}$ (nochange_model)

mean(abs(nochange_model\$residuals))

sqrt(mean(nochange_model\$residuals`2))

\#\#\#Simple linear

linear_model $=\operatorname{lm}($ ts.rarely $\sim$ time $($ ts.rarely $))$

AIC(linear_model)

BIC(linear_model)

logLik(linear_model)

mean(abs(linear_model\$residuals))

sqrt(mean(linear_model\$residuals^2))

\#\#\#Fixed breakpoints

bps1 = breakpoints(ts.rarely $\sim 1, \mathrm{~h}=2$ )

plot(bps1)

bfs 1 = breakfactor $($ bps1, breaks = length (bps1 $\$$ breakpoints $))$

breakpoint_model $1=\operatorname{lm}($ ts.rarely $\sim$ bfs $1-1)$

AIC(breakpoint_model1)

BIC(breakpoint_model1)

logLik(breakpoint_model1)

mean(abs(breakpoint_model1\$residuals))

sqrt(mean(breakpoint_model1\$residuals^2))

\#\#\#Plot breakpoints

plot(ts.rarely, ylab = "Suicide terrorism is rarely justified", xlab = "year")

lines(ts(predict(nochange_model), $\operatorname{start}=\mathrm{c}(2004)$, end $=\mathrm{c}(2011))$

, col='red'

, lwd $=2$ )

lines(ts(predict(linear_model), start $=\mathrm{c}(2004)$, end $=\mathrm{c}(2011))$

, col='darkgreen'

, lwd $=2)$

lines(ts(predict(breakpoint_model1), start $=c(2004)$, end $=c(2011))$

, col='orange'

, lwd $=2$ )

\#\#Never

\#\#\#Stationary

adf.test (ts.never, alternative $=$ "stationary")

nochange_model $=\operatorname{lm}($ ts.never $\sim 1$ )

AIC(nochange_model)

BIC(nochange_model)

logLik(nochange_model)

mean(abs(nochange_model\$residuals))

sqrt(mean(nochange_model\$residuals $\left.{ }^{\wedge} 2\right)$ )

\#\#\#Simple linear

linear_model $=\operatorname{lm}($ ts.never $\sim$ time $($ ts.never $))$ 


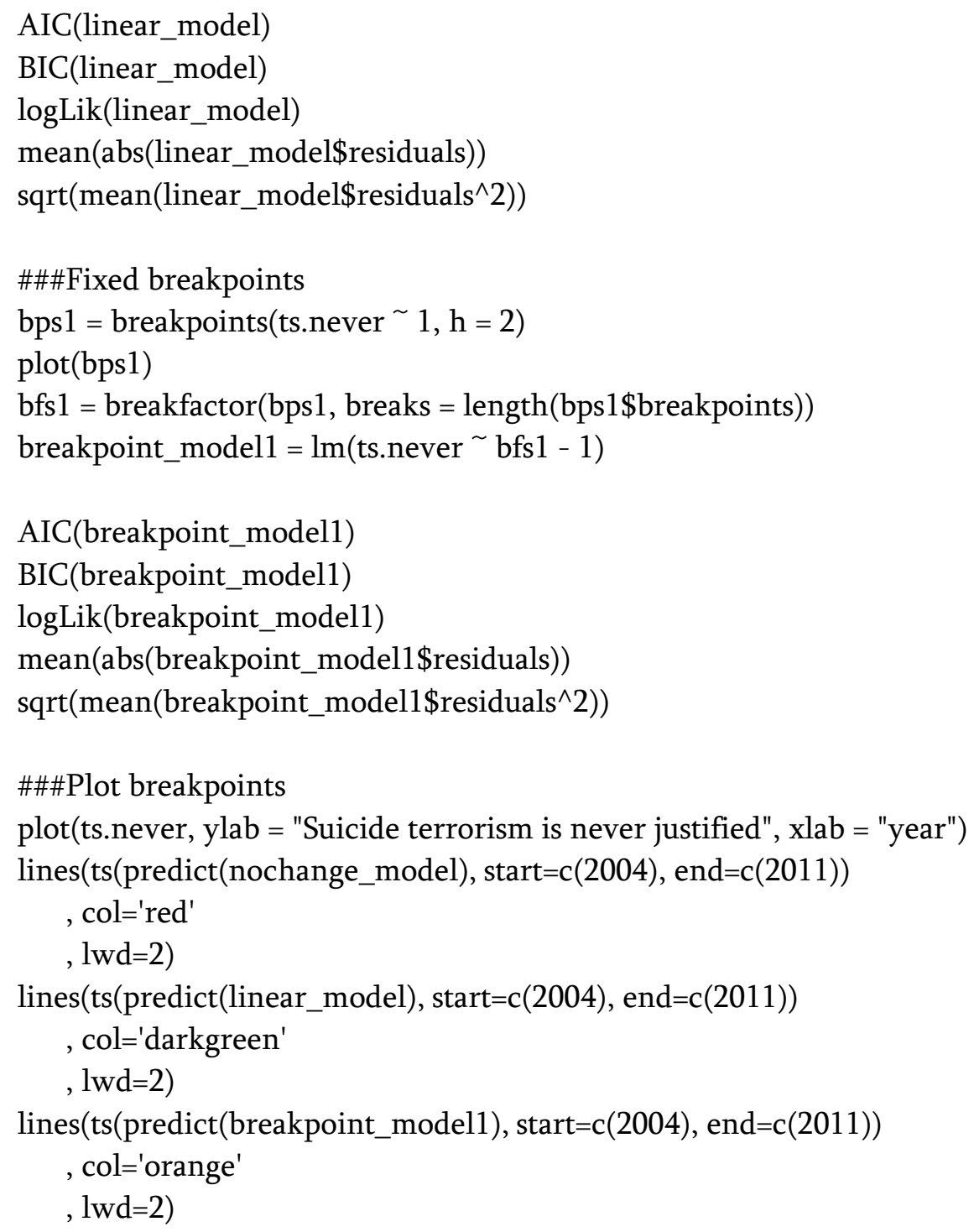


bps1 = breakpoints(ts.often_sometimes $\sim 1, \mathrm{~h}=2)$

plot(bps1)

bfs1 = breakfactor(bps1, breaks = length (bps1\$breakpoints))

breakpoint_model $1=\operatorname{lm}($ ts.often_sometimes $\sim$ bfs $1-1)$

AIC(breakpoint_model1)

BIC(breakpoint_model1)

$\operatorname{logLik}$ (breakpoint_model1)

mean(abs(breakpoint_model1\$residuals))

sqrt(mean(breakpoint_model1\$residuals^2))

\#\#\#Plot breakpoints

plot(ts.often_sometimes, ylab = "Suicide terrorism is often_sometimes justified", xlab = "year")

lines(ts(predict(nochange_model), $\operatorname{start}=c(2004)$, end $=c(2011))$

, col='red'

, lwd $=2$ )

lines(ts(predict(linear_model), start $=\mathrm{c}(2004)$, end $=\mathrm{c}(2011))$

, col='darkgreen'

, lwd $=2$ )

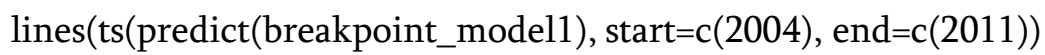

, col='orange'

, lwd=2)

\#\#Often_sometimes (sum)

\#\#\#\#Stationary

adf.test(ts.os_sum, alternative $=$ "stationary")

nochange_model $=\operatorname{lm}$ (ts.os_sum $\sim 1$ )

AIC(nochange_model)

BIC(nochange_model)

logLik(nochange_model)

mean(abs(nochange_model\$residuals))

sqrt(mean(nochange_model\$residuals`2))

\#\#\#\#imple linear

linear_model $=\operatorname{lm}($ ts.os_sum $\sim$ time $($ ts.os_sum $))$

AIC(linear_model)

BIC(linear_model)

logLik(linear_model)

mean(abs(linear_model\$residuals))

sqrt(mean(linear_model\$residuals^2))

\#\#\#\#ixed breakpoints

bps1 = breakpoints(ts.os_sum $~ 1, \mathrm{~h}=2$ )

plot(bps1)

bfs1 = breakfactor(bps1, breaks = length (bps1 \$breakpoints))

breakpoint_model $1=\operatorname{lm}($ ts.os_sum $\sim$ bfs $1-1)$

AIC(breakpoint_model1)

BIC(breakpoint_model1) 
$\operatorname{logLik}$ (breakpoint_model1)

mean(abs(breakpoint_model1\$residuals))

$\operatorname{sqrt}\left(\right.$ mean(breakpoint_model1\$residuals $\left.{ }^{\wedge} 2\right)$ )

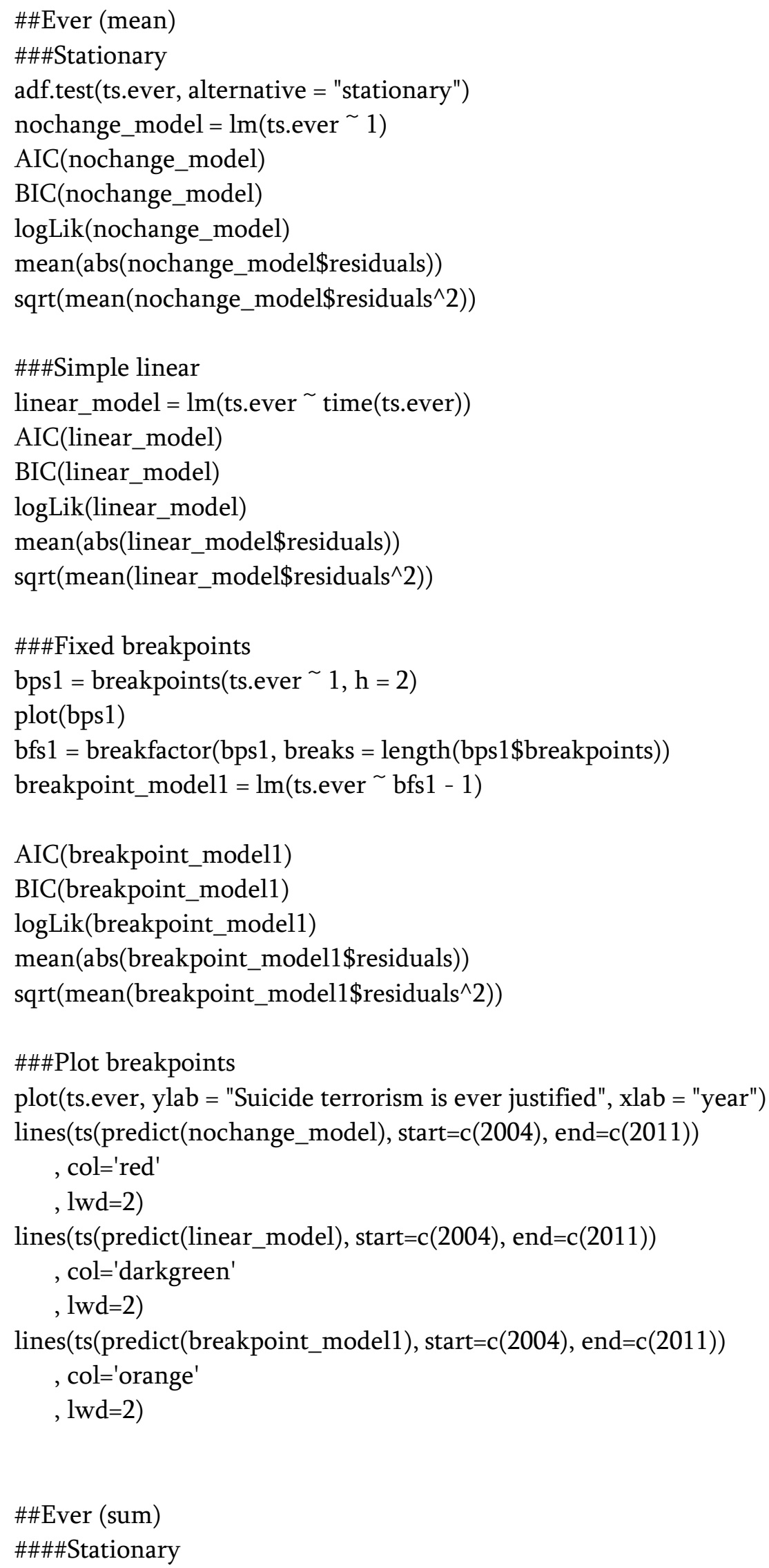


adf.test(ts.ever_sum, alternative = "stationary")

nochange_model $=\operatorname{lm}($ ts.ever_sum $\sim 1)$

AIC(nochange_model)

BIC(nochange_model)

logLik(nochange_model)

mean(abs(nochange_model\$residuals))

sqrt(mean(nochange_model\$residuals^2))

\#\#\#)Simple linear

linear_model $=\operatorname{lm}($ ts.ever_sum $\sim$ time $($ ts.ever_sum $))$

AIC(linear_model)

BIC(linear_model)

$\operatorname{logLik}($ linear_model)

mean(abs(linear_model\$residuals))

sqrt(mean(linear_model\$residuals`2))

\#\#\#\#Fixed breakpoints

bps1 = breakpoints(ts.ever_sum $\sim 1, \mathrm{~h}=2$ )

plot(bps1)

bfs1 = breakfactor (bps1, breaks = length(bps1 \$breakpoints)

breakpoint_model $1=\operatorname{lm}($ ts.ever_sum $\sim$ bfs $1-1)$

AIC(breakpoint_model1)

BIC(breakpoint_model1)

$\operatorname{logLik}$ (breakpoint_model1)

mean(abs(breakpoint_model1\$residuals))

$\operatorname{sqrt}($ mean(breakpoint_model1\$residuals^2))

\#Supplementary analysis Jordan and Turkey: data creation (RUN MODELS AS ABOVE)

\#\#create data often Jordan

waves $<-c(1,2,3,4,5,6,7,8)$

often $<-\mathrm{c}(31.7,24.3,4.6,5.8,7,3.7,8.5,3.5)$

data $<$-data.frame $($ Year $=$ waves, $\mathrm{DV}=$ often $)$

\#\#plot data often Jordan

ts.often $=\operatorname{ts}($ data $=$ data $\$ D V$, start $=c(2004)$, end $=c(2011)$, frequency $=1)$

plot(ts.often, ylab = "Suicide terrorism is often justified")

\#\#create data sometimes Jordan

waves $<-c(1,2,3,4,5,6,7,8)$

sometimes<-c $(49.9,32.6,24.1,16.7,17.8,7.7,12.1,9.1)$

data $<$-data.frame $($ Year $=$ waves, $\mathrm{DV}=$ sometimes $)$

\#\#plot data sometimes Jordan

ts.sometimes $=$ ts $($ data $=$ data $\$ D V$, start $=c(2004)$, end $=c(2011)$, frequency=1)

plot(ts.sometimes, ylab = "Suicide terrorism is sometimes justified") 
\#\#create data rarely Jordan

waves $<-c(1,2,3,4,5,6,7,8)$

rarely<-c(13.8, 31, 27.7, 27, 29.1, 26.2, 24.6, 30.8)

data $<$-data.frame $($ Year $=$ waves, $\mathrm{DV}=$ rarely $)$

\#\#plot data rarely Jordan

ts.rarely $=\operatorname{ts}($ data $=$ data $\$ D V$, start $=c(2004)$, end $=c(2011)$, frequency $=1)$

plot(ts.rarely, ylab = "Suicide terrorism is rarely justified")

\#\#create data never Jordan

waves $<-\mathrm{c}(1,2,3,4,5,6,7,8)$

never $<-c(2.9,11.1,43.1,42.4,40.9,56,53.8,54.6)$

data $<$-data.frame $($ Year $=$ waves, $\mathrm{DV}=$ never $)$

\#\#plot data never Jordan

ts.never $=\mathrm{ts}($ data $=$ data\$DV, start $=c(2004)$, end $=c(2011)$, frequency $=1)$

plot(ts.never, ylab = "Suicide terrorism is never justified")

\#\#create data ever Jordan

waves $<-c(1,2,3,4,5,6,7,8)$

ever $<-c(27.3,29.8,21.1,20.6,24.2,15.9,17.5,18.6)$

data $<$-data.frame $($ Year $=$ waves, $D V=$ ever $)$

\#\#plot data ever Jordan

ts.ever $=\mathrm{ts}($ data $=$ data $\$ D V$, start $=c(2004)$, end $=c(2011)$, frequency $=1)$

plot(ts.ever, ylab = "Suicide terorrism is ever justified")

\#\#create data often_sometimes Jordan

waves $<-c(1,2,3,4,5,6,7,8)$

often_sometimes $<-c(40.8,28.5,14.4,14.2,19.4,5.7,10.3,6.3)$

data $<$-data.frame $($ Year $=$ waves, $\mathrm{DV}=$ often_sometimes $)$

\#\#plot data often_sometimes Jordan

ts.often_sometimes $=\mathrm{ts}($ data $=$ data $\$ D V$, start $=c(2004)$, end $=c(2011)$, frequency $=1)$

plot(ts.often_sometimes, ylab = "Suicide terrorism is often/sometimesjustified")

\#\#create data often Turkey

waves $<-c(1,2,3,4,5,6,7,8)$

often $<-c(5.5,3.3,2.8,3.3,1.3,0.9,1.8,1.8)$

data $<$-data.frame $($ Year $=$ waves, $\mathrm{DV}=$ often $)$

\#\#plot data often Turkey

ts.often $=\operatorname{ts}($ data $=$ data $\$ D V$, start $=c(2004)$, end $=c(2011)$, frequency $=1)$

plot(ts.often, ylab = "Suicide terrorism is often justified")

\#\#create data sometimes Turkey

waves $<-c(1,2,3,4,5,6,7,8)$

sometimes $<-\mathrm{c}(8.8,11.2,13.6,13,2.1,2.7,4.1,5.3)$ 
data $<$-data.frame $($ Year $=$ waves, $\mathrm{DV}=$ sometimes $)$

\#\#plot data sometimes Turkey

ts. sometimes $=\operatorname{ts}($ data $=$ data $\$ D V$, start $=c(2004)$, end $=c(2011)$, frequency=1)

plot(ts.sometimes, ylab = "Suicide terrorism is sometimes justified")

\#\#create data rarely Turkey

waves $<-\mathrm{c}(1,2,3,4,5,6,7,8)$

rarely<-c(9.3, 6.2, 8.8, 8.8, 5.9, 5.1, 3.8, 13.6)

data $<$-data.frame $($ Year $=$ waves, $\mathrm{DV}=$ rarely $)$

\#\#plot data rarely Turkey

ts.rarely $=\operatorname{ts}($ data $=$ data $\$ D V$, start $=c(2004)$, end $=c(2011)$, frequency $=1)$

plot(ts.rarely, ylab = "Suicide terrorism is rarely justified")

\#\#create data never Turkey

waves $<-\mathrm{c}(1,2,3,4,5,6,7,8)$

never $<-\mathrm{c}(67.4,66.3,61,55.7,81.8,73.8,76.3,60.7)$

data $<$-data.frame $($ Year $=$ waves, $\mathrm{DV}=$ never $)$

\#\#plot data never Turkey

ts.never $=\mathrm{ts}($ data $=$ data\$DV, start $=\mathrm{c}(2004)$, end $=\mathrm{c}(2011)$, frequency $=1)$

plot(ts.never, ylab = "Suicide terrorism is never justified")

\#\#create data ever Turkey

waves $<-c(1,2,3,4,5,6,7,8)$

ever $<-c(8.2,9.9,8.5,8.5,3.8,3.5,2.9,8.6)$

data $<$-data.frame $($ Year $=$ waves, $\mathrm{DV}=$ ever $)$

\#\#plot data ever Turkey

ts.ever $=$ ts $($ data $=$ data $\$ D V$, start $=c(2004)$, end $=c(2011)$, frequency $=1)$

plot(ts.ever, ylab = "Suicide terorrism is ever justified")

\#\#create data often_sometimes Turkey

waves $<-c(1,2,3,4,5,6,7,8)$

often_sometimes $<-c(7.15,7.3,8.1,8.2,1.7,1.8,2.9,3.6)$

data $<$-data.frame $($ Year $=$ waves, DV $=$ often_sometimes $)$

\#\#plot data often_sometimes Turkey

ts.often_sometimes $=\mathrm{ts}($ data $=$ data $\$ D V$, start $=c(2004)$, end $=c(2011)$, frequency $=1)$

plot(ts.often_sometimes, ylab = "Suicide terrorism is often/sometimesjustified") 


\section{Supplementary Material}

Note 1

Table S1. Raw data 2004.

\begin{tabular}{llllll}
\hline & Often justified & Sometimes justified & Rarely justified & Never justified & Don't know \\
\hline Jordan* & $31.7 \%$ & $49.9 \%$ & $13.8 \%$ & $2.9 \%$ & $1.3 \%$ \\
Turkey & $5.5 \%$ & $8.8 \%$ & $9.3 \%$ & $67.4 \%$ & $8.6 \%$ \\
\hline
\end{tabular}

*In 2004, the question that was being asked in Jordan did not make reference to 'Islam'; this was changed in the following waves but we decided to include data from 2004 as well.

Table S2. Raw data 2005.

\begin{tabular}{|c|c|c|c|c|c|}
\hline & Often justified & Sometimes justified & Rarely justified & Never justified & Don't know \\
\hline Jordan & $24.3 \%$ & $32.6 \%$ & $31 \%$ & $11.1 \%$ & $0.8 \%$ \\
\hline Turkey & $3.3 \%$ & $11.2 \%$ & $6.2 \%$ & $66.3 \%$ & $12.9 \%$ \\
\hline Indonesia & $2.1 \%$ & $12.6 \%$ & $17.9 \%$ & $66 \%$ & $1.4 \%$ \\
\hline Lebanon & $25.8 \%$ & $13.1 \%$ & $18.6 \%$ & $33 \%$ & $9.6 \%$ \\
\hline \multicolumn{6}{|c|}{ Table S3. Raw data 2006.} \\
\hline & Often justified & Sometimes justified & Rarely justified & Never justified & Don't know \\
\hline Jordan & $4.6 \%$ & $24.1 \%$ & $27.7 \%$ & $43.1 \%$ & $0.2 \%$ \\
\hline Turkey & $2.8 \%$ & $13.6 \%$ & $8.8 \%$ & $61 \%$ & $12.5 \%$ \\
\hline Indonesia & $1.8 \%$ & $8.4 \%$ & $17.6 \%$ & $71.2 \%$ & $0.9 \%$ \\
\hline Egypt & $8.1 \%$ & $19.6 \%$ & $24.8 \%$ & $44.8 \%$ & $2.6 \%$ \\
\hline Nigeria & $7.7 \%$ & $38.2 \%$ & $22.6 \%$ & $28 \%$ & $3.2 \%$ \\
\hline
\end{tabular}


Table S4. Raw data 2007.

\begin{tabular}{|c|c|c|c|c|c|}
\hline & Often justified & Sometimes justified & Rarely justified & Never justified & Don't know \\
\hline Jordan & $5.8 \%$ & $16.7 \%$ & $27 \%$ & $42.4 \%$ & $3.5 \%$ \\
\hline Turkey & $3.3 \%$ & $13 \%$ & $8.8 \%$ & $55.7 \%$ & $17.5 \%$ \\
\hline Indonesia & $3 \%$ & $6.4 \%$ & $12.5 \%$ & $76.5 \%$ & $1.6 \%$ \\
\hline Lebanon & $10.4 \%$ & $24 \%$ & $22.6 \%$ & $42.1 \%$ & $0.8 \%$ \\
\hline Egypt & $2.4 \%$ & $6.4 \%$ & $42.7 \%$ & $39.7 \%$ & $2.7 \%$ \\
\hline Nigeria & $9.8 \%$ & $32 \%$ & $10.8 \%$ & $39.3 \%$ & $6.7 \%$ \\
\hline Bangladesh & $6.3 \%$ & $14.1 \%$ & $3.5 \%$ & $72.8 \%$ & $3.3 \%$ \\
\hline Ethiopia & $6.8 \%$ & $14.8 \%$ & $11.8 \%$ & $59.5 \%$ & $3 \%$ \\
\hline Senegal & $5.3 \%$ & $13 \%$ & $14.6 \%$ & $62.7 \%$ & $4.1 \%$ \\
\hline Tanzania & $3.9 \%$ & $7 \%$ & $8.9 \%$ & $71.2 \%$ & $5.4 \%$ \\
\hline Kuwait & $8.7 \%$ & $11.8 \%$ & $6.8 \%$ & $68.9 \%$ & $3 \%$ \\
\hline Morocco & $5.5 \%$ & $5 \%$ & $8.6 \%$ & $68.8 \%$ & $11.2 \%$ \\
\hline Mali & $21.5 \%$ & $17.5 \%$ & $16.5 \%$ & $36.8 \%$ & $6.3 \%$ \\
\hline $\begin{array}{l}\text { Palestinian } \\
\text { Territories }\end{array}$ & $40.7 \%$ & $29.3 \%$ & $12.7 \%$ & $8.2 \%$ & $6.2 \%$ \\
\hline & Often justified & Sometimes justified & Rarely justified & Never justified & Don't know \\
\hline Jordan & $7 \%$ & $17.8 \%$ & $29.1 \%$ & $40.9 \%$ & $5 \%$ \\
\hline Turkey & $1.3 \%$ & $2.1 \%$ & $5.9 \%$ & $81.8 \%$ & $8.3 \%$ \\
\hline Indonesia & $3 \%$ & $8.1 \%$ & $12.2 \%$ & $74 \%$ & $2.5 \%$ \\
\hline Lebanon & $6.6 \%$ & $22 \%$ & $21.6 \%$ & $48.3 \%$ & $1.1 \%$ \\
\hline Egypt & $3.5 \%$ & $8.5 \%$ & $40.2 \%$ & $39.8 \%$ & $4.2 \%$ \\
\hline Nigeria & $11.3 \%$ & $21.3 \%$ & $11.6 \%$ & $49.4 \%$ & $6.1 \%$ \\
\hline
\end{tabular}


Table S6. Raw data 2009.

\begin{tabular}{llllll}
\hline & Often justified & Sometimes justified & Rarely justified & Never justified & Don't know \\
\hline Jordan & $3.7 \%$ & $7.7 \%$ & $26.2 \%$ & $56 \%$ & $6.4 \%$ \\
Turkey & $0.9 \%$ & $2.7 \%$ & $5.1 \%$ & $73.8 \%$ & $14.5 \%$ \\
Indonesia & $3.2 \%$ & $9.6 \%$ & $20.1 \%$ & $65.6 \%$ & $1.5 \%$ \\
Lebanon & $10.9 \%$ & $24.7 \%$ & $19.8 \%$ & $44.4 \%$ & $0.2 \%$ \\
Egypt & $5.1 \%$ & $9.7 \%$ & $23.4 \%$ & $51.5 \%$ & $10.1 \%$ \\
Nigeria & $15.1 \%$ & $28.3 \%$ & $19.4 \%$ & $33.3 \%$ & $2.8 \%$ \\
Israel & $3.4 \%$ & $4.1 \%$ & $25.6 \%$ & $55.3 \%$ & $7.2 \%$ \\
Palestinian & $37.2 \%$ & $31.5 \%$ & $13.2 \%$ & $16.3 \%$ & $1.4 \%$ \\
Territories & & & & \\
\hline
\end{tabular}

Table S7. Raw data 2010.

\begin{tabular}{llllll} 
& Often justified & Sometimes justified & Rarely justified & Never justified & Don't know \\
\hline Jordan & $8.5 \%$ & $12.1 \%$ & $24.6 \%$ & $53.8 \%$ & $0.8 \%$ \\
Turkey & $1.8 \%$ & $4.1 \%$ & $3.8 \%$ & $76.3 \%$ & $12.6 \%$ \\
Indonesia & $4.6 \%$ & $10.9 \%$ & $13.4 \%$ & $69.2 \%$ & $2 \%$ \\
Lebanon & $14.6 \%$ & $23.6 \%$ & $21.3 \%$ & $39.5 \%$ & $0.5 \%$ \\
Egypt & $7.6 \%$ & $12.4 \%$ & $34.1 \%$ & $45.7 \%$ & $0 \%$ \\
Nigeria & $11.1 \%$ & $24.2 \%$ & $17.8 \%$ & $41.3 \%$ & $5.4 \%$ \\
\hline
\end{tabular}


Table S8. Raw data 2011.

\begin{tabular}{llllll}
\hline & Often justified & Sometimes justified & Rarely justified & Never justified & Don't know \\
\hline Jordan & $3.5 \%$ & $9.1 \%$ & $30.8 \%$ & $54.6 \%$ & $1.9 \%$ \\
Turkey & $1.8 \%$ & $5.3 \%$ & $13.6 \%$ & $60.7 \%$ & $12.4 \%$ \\
Indonesia & $1.5 \%$ & $8.4 \%$ & $11.1 \%$ & $77.2 \%$ & $1.4 \%$ \\
Lebanon & $12.3 \%$ & $22.6 \%$ & $24.1 \%$ & $40.7 \%$ & $0.4 \%$ \\
Egypt & $11.7 \%$ & $15.5 \%$ & $33.7 \%$ & $38 \%$ & $0.6 \%$ \\
Nigeria & $15.1 \%$ & $28.3 \%$ & $19.4 \%$ & $33.3 \%$ & $2.8 \%$ \\
Israel & $5.1 \%$ & $15.6 \%$ & $26.9 \%$ & $40.8 \%$ & $7.5 \%$ \\
Palestinian & $31 \%$ & $37.2 \%$ & $9.6 \%$ & $18.6 \%$ & $3.3 \%$ \\
Territories & & & & & \\
\hline
\end{tabular}


Note 2

Table S9. Number of suicide attacks. Source: Global Terrorism Database.

\begin{tabular}{|c|c|c|c|c|c|c|c|c|c|c|c|c|}
\hline & 2000 & 2001 & 2002 & 2003 & 2004 & 2005 & 2006 & 2007 & 2008 & 2009 & 2010 & 2011 \\
\hline Jordan & & & & & & 3 & & & & & & \\
\hline Turkey & 1 & 2 & & 5 & 1 & 1 & 2 & & 1 & 1 & & 2 \\
\hline Indonesia & & 1 & 2 & 1 & 1 & 2 & & & & 2 & & 2 \\
\hline Lebanon & & & & & & & 1 & 1 & 1 & & & \\
\hline Egypt & & & & & 3 & 2 & & & & & & 2 \\
\hline Nigeria & & & & & & & & & & & & 4 \\
\hline Bangladesh & & 1 & & & & 6 & & & & & 1 & \\
\hline Ethiopia & & & & & & & & & & & & \\
\hline Israel & & 24 & 43 & 15 & 7 & 5 & 3 & 1 & 3 & & 1 & 1 \\
\hline Senegal & & & & & & & & & & & & \\
\hline Tanzania & & & & & & & & & & & & \\
\hline Kuwait & & & & & & & & & & & & \\
\hline Morocco & & & & 7 & & & & 6 & & & & \\
\hline Mali & & & & & & & & & & & & \\
\hline Palestinian & & & & & & & & & & & & \\
\hline Territories & & & & & & & & & & & & \\
\hline
\end{tabular}


Note 3

Table S10. Model fit for analyses including only Jordan.

\begin{tabular}{|c|c|c|c|c|c|}
\hline Outcome measure & Model & AIC & BIC & MAE & RMSE \\
\hline \multirow{3}{*}{$\begin{array}{l}\text { Often justified } \\
\text { Dickey-Fuller Statistic }=-5.26, p=.01\end{array}$} & Stationary & 63.59 & 63.75 & 8.43 & 10.03 \\
\hline & Linear & 58.82 & 59.06 & 5.86 & 6.57 \\
\hline & Breakpoint (1) & 42.82 & 43.07 & 2.11 & 2.42 \\
\hline \multirow{3}{*}{$\begin{array}{l}\text { Sometimes justified } \\
\text { Dickey-Fuller Statistic }=-1.62, \mathrm{p}=.714\end{array}$} & Stationary & 68.05 & 68.21 & 10.71 & 13.25 \\
\hline & Linear & 56.94 & 57.17 & 5.08 & 5.84 \\
\hline & Breakpoint (1) & 56.11 & 56.43 & 3.92 & 4.89 \\
\hline \multirow{3}{*}{$\begin{array}{l}\text { Rarely justified } \\
\text { Dickey-Fuller Statistic }=-2.19, \mathrm{p}=.499\end{array}$} & Stationary & 52.91 & $\mathbf{5 3 . 0 7}$ & 3.56 & 5.15 \\
\hline & Linear & 53.11 & 53.35 & 3.68 & 4.60 \\
\hline & Breakpoint (0) & 53.24 & 53.47 & 3.38 & 4.63 \\
\hline \multirow{3}{*}{$\begin{array}{l}\text { Never justified } \\
\text { Dickey-Fuller Statistic }=-3.86, \mathrm{p}=.032\end{array}$} & Stationary & 73.73 & 73.89 & 15.55 & 18.90 \\
\hline & Linear & 63.57 & 63.80 & 7.71 & 8.84 \\
\hline & Breakpoint (1) & 43.30 & 43.62 & 1.63 & 2.20 \\
\hline \multirow{3}{*}{$\begin{array}{l}\text { Ever justified } \\
\text { Dickey-Fuller Statistic }=-6.12, \mathrm{p}=.01\end{array}$} & Stationary & 50.94 & 51.09 & 3.92 & 4.55 \\
\hline & Linear & 44.54 & 44.78 & 2.34 & 2.69 \\
\hline & Breakpoint (2) & 35.42 & 35.73 & 1.23 & 1.34 \\
\hline \multirow{3}{*}{$\begin{array}{l}\text { Often/sometimes justified } \\
\text { Dickey-Fuller Statistic }=-3.58, p=.053\end{array}$} & Stationary & 65.37 & 65.52 & 9.09 & 11.21 \\
\hline & Linear & 56.59 & 56.82 & 5.04 & 5.71 \\
\hline & Breakpoint (2) & 51.34 & 51.66 & 3.10 & 3.63 \\
\hline
\end{tabular}


Table S11. Model fit for analyses including only Turkey.

\begin{tabular}{|c|c|c|c|c|c|}
\hline Outcome measure & Model & AIC & BIC & MAE & RMSE \\
\hline \multirow{3}{*}{$\begin{array}{l}\text { Often justified } \\
\text { Dickey-Fuller Statistic }=-1.43, p=.791\end{array}$} & Stationary & 31.88 & 32.04 & 1.14 & 1.38 \\
\hline & Linear & 25.31 & 25.55 & .76 & 0.81 \\
\hline & Breakpoint (1) & 24.84 & 25.08 & .62 & 0.79 \\
\hline \multirow{3}{*}{$\begin{array}{l}\text { Sometimes justified } \\
\text { Dickey-Fuller Statistic }=-2.42, \mathrm{p}=.412\end{array}$} & Stationary & 50.22 & 50.83 & 4.05 & 4.35 \\
\hline & Linear & 47.84 & 48.08 & 2.87 & 3.31 \\
\hline & Breakpoint (2) & 31.86 & 32.18 & .95 & 1.08 \\
\hline \multirow{3}{*}{$\begin{array}{l}\text { Rarely justified } \\
\text { Dickey-Fuller Statistic }=-1.39, \mathrm{p}=.803\end{array}$} & Stationary & 43.73 & 43.89 & 2.44 & 2.90 \\
\hline & Linear & 45.72 & 45.96 & 2.46 & 2.90 \\
\hline & Breakpoint (0) & 45.40 & 45.64 & 2.14 & 2.84 \\
\hline \multirow{3}{*}{$\begin{array}{l}\text { Never justified } \\
\text { Dickey-Fuller Statistic }=-1.44, p=.787\end{array}$} & Stationary & 60.54 & 60.70 & 7.07 & 8.29 \\
\hline & Linear & 62.14 & 62.37 & 6.86 & 8.08 \\
\hline & Breakpoint (1) & 58.39 & 58.63 & 5.24 & 6.39 \\
\hline \multirow{3}{*}{$\begin{array}{l}\text { Ever justified } \\
\text { Dickey-Fuller Statistic }=-.47, p=.977\end{array}$} & Stationary & 42.22 & 42.38 & 2.50 & 2.64 \\
\hline & Linear & 41.50 & 41.74 & 1.98 & 2.23 \\
\hline & Breakpoint (1) & 36.96 & 37.20 & 1.26 & 1.68 \\
\hline \multirow{3}{*}{$\begin{array}{l}\text { Often/sometimes justified } \\
\text { Dickey-Fuller Statistic }=-2.25, p=.475\end{array}$} & Stationary & 42.44 & 42.60 & 2.59 & 2.67 \\
\hline & Linear & 38.17 & 38.41 & 1.49 & 1.81 \\
\hline & Breakpoint (2) & 14.99 & 15.31 & 0.33 & 0.37 \\
\hline
\end{tabular}


